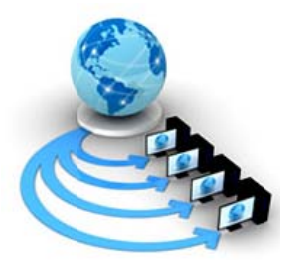

Volume 9, No. 1, January-February 2018

International Journal of Advanced Research in Computer Science

REVIEW ARTICLE

\author{
Available Online at www.ijarcs.info
}

\title{
A COMPARATIVE ANALYSIS OF ASSORTED DEEP AND MACHINE LEARNING TECHNIQUES FOR AUTOMATED EARLY DIAGNOSIS OF DIABETIC RETINOPATHY
}

\author{
Er. Emmy Bhatti \\ M.tech, Dept of CET, GNDU, \\ Amritsar, Punjab, India
}

\author{
Er. Prabhpreet Kaur, \\ Asst prof. Dept of CET, GNDU \\ Amritsar, Punjab, India
}

\begin{abstract}
Diabetic retinopathy is the most common form of diabetic eye disease. Diabetic retinopathy (DR) usually only affects people who have had diabetes (diagnosed or undiagnosed) for a significant number of years. In spite of DR not being a curable illness, it can be treated if it is detected in its early stages. The main objective of this paper is to review the various deep learning, machine learning approaches in correspondence with image processing for diagnosing Diabetic Retinopathy as early as possible. Firstly, we have a look at how automated detection systems are constructed and highlight various features used for the purpose of DR diagnosis. Next we analyze the existing work in the field focusing both techniques individually. The papers have been compared and contrasted based on qualitative and qualitative parameters viz., purpose of the work, algorithms adopted and results obtained. Finally, we present an overall comparison between deep learning and machine learning algorithms used to detect diabetic retinopathy and conclude why deep learning approaches provide best results when it comes to early detection of the disease.
\end{abstract}

Keywords: Diabetic retinopathy, Automated diagnosis, Deep learning, Machine learning, Lesion detection.

\section{INTRODUCTION}

Diabetic retinopathy (DR) is a chronic disease related with the eye retina which presently comprises of one of the most common causes of blindness and loss of vision. The incidental statistics indicate that DR is the primary cause of blindness in people of working age of the present era. DR is an outcome of diabetes-mellitus, illness which elevates the concentration of glucose in blood. This unusually high glucose levels damage the eye vessel endothelium infuriating set of damages related to the illness. Although having diabetes does not necessarily entail vision mutilation, about $2 \%$ of the patients affected by this disease are blind and $10 \%$ undergo vision deprivation after 15 years of diabetes as a result of DR complications. Vision-threatening retinopathy is rare in type 1 diabetic patients in the first 3-5 years of diabetes or before puberty. During the next two decades, nearly all type 1 diabetic patients develop retinopathy. Up to $21 \%$ of patients with type 2 diabetes have retinopathy at the time of first diagnosis of diabetes, and most develop some degree of retinopathy over time. The estimated prevalence of diabetes for all age groups worldwide was $2.8 \%$ in 2000 and will be $4.4 \%$ in 2030 .

Despite DR being an incurable disease, if the illness is detected and treated in its early stages visual impairment can be avoided in $98 \%$ of cases. In this respect, though laser photocoagulation has established to be a successful treatment for preventing major loss of vision produced by DR yet the early detection of the illness is still a difficult task since people affected by it do not recognize symptoms until visual loss develops which usually happens in the later disease stages, when treatment loses its effectiveness. This is why the prone diabetic population has to be examined periodically by public or private health systems in search of early DR signs. However, this preventive action involves a daring confrontation by the health systems due to the high number of ophthalmologists and material resources needed to attend so many patients requiring ophthalmologic revision.

\subsection{Automated detection of $D R$}

The advantageous and cost-effective disposition of screening programs for early detection of DR is wellrecognized. However, a great challenge for health systems is their efficient development due to the involvement of the great amount of human and material resources. If an automated system could be able to eliminate a large number of those patients unaffected by DR, it would diminish the workload of the specialists and thus enhancing the preventive protocols.

Thus, more financial advantages will bring about for general wellbeing frameworks, since striking cost investment funds connect with such practical early disease location medicines. Therefore, more monetary advantages will bring about for general wellbeing frameworks, since surprising cost reserve funds connect with such savvy early ailment discovery medicines. 


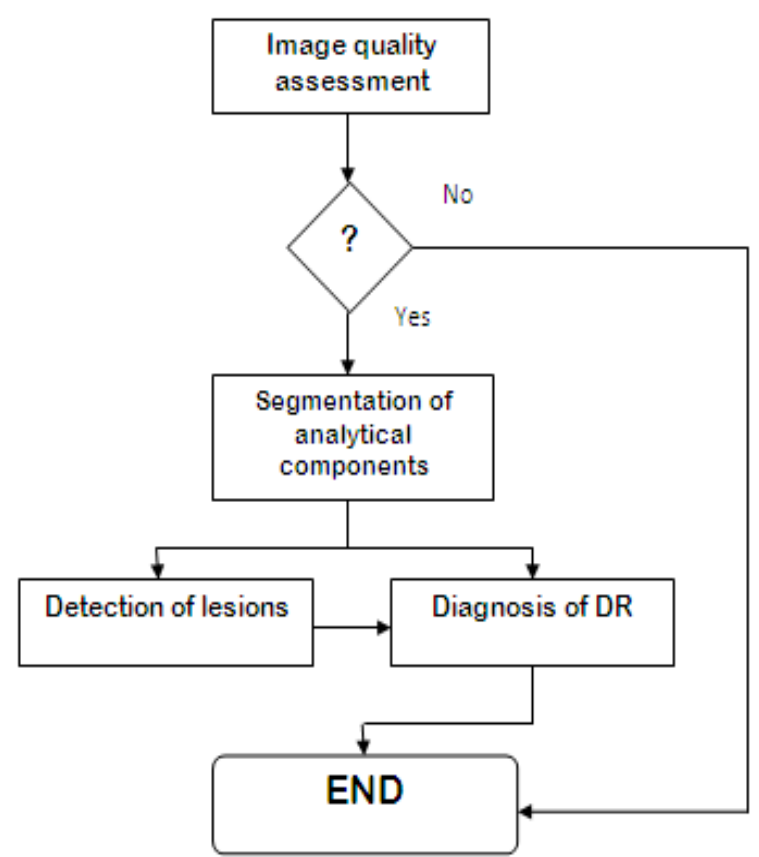

Fig:- Automated detection of DR flowchart for any random algorithm

The construction of a generic all-inclusive system for the diagnosis of DR may be structurally and logically divided into four general phases, namely Image Quality Assessment, Segmentation of the main anatomical components of the retina viz., optic disc, vascular tree and macula, Detection of lesions produced by DR and lastly Implementation of the expert system as shown in the diagram. Each of these phases produces as a result a logical module of the system which gives support to its underlying modules resulting in a structure with strong unidirectional coupling between modules.

\subsection{Detection of various lesions produced by $D R$ as an essential step of early DR detection}

- Detection of microaneurysms: Microaneurysms are the most primitive signs of DR, hence, their accurate detection and segmentation is of critical importance for automated early DR detection. They look like very small red dots on the retinal surface. On one hand, their invariable shape and color are very clear make these easy to discover but on the other hand their tiny size makes their accurate detection a very challenging task.

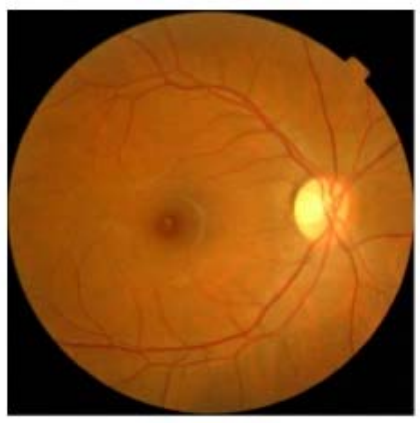

(a)
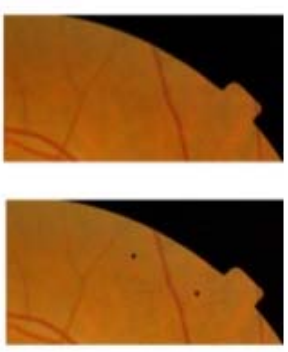

(b)
Fig:- Detection of microaneurysms: (a) retinography of a patient affected by DR in early stages, (b) the upper image on the right is a fragment of (a), and the bottom image on the right is the same sub-image with two microaneurysms segmented.

- Detection of hemorrhages: Hemorrhages occur due to microaneurysms explosion or breaking of vessels which makes them very unspecific in shape and size, thus their red color is the only distinguishable feature of hemorrhages. Also, tiny hemorrhages may be very difficult to be differentiated from microaneurysms. As a result, the literature is sparse in explicit works for detecting and segmenting only hemorrhages, therefore, a combined segmentation along with microaneurysms known as detection of red lesions is more prevalent in most of the existing works.
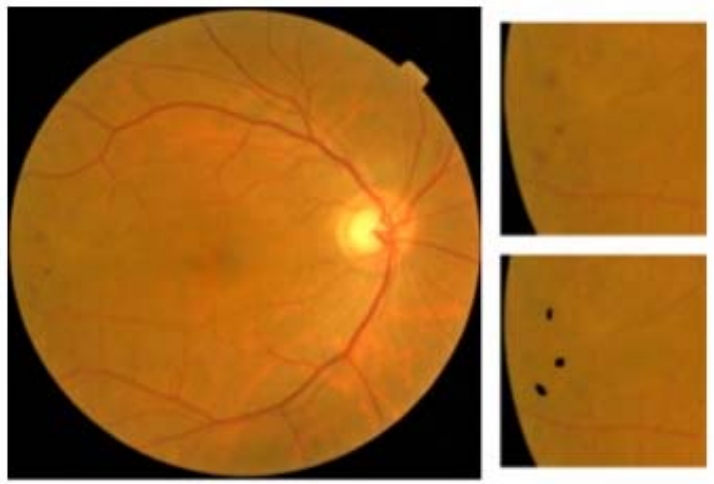

(a)

(b)

Fig:- Detection of hemorrhages: (a) original image of a patient affected by DR, (b) the upper image on the right shows a hemorrhage-containing subimage, and the bottom image on the right shows segmentation of the lesions.

- Detection of exudates: These lesions emerge on the retinal surface as yellowish or whitish patches well distinguished from the retinal tissue with variable size. Therefore, attending to exudates features, this lesion produced by DR is comparatively segment. However, this aspect does not underrate the significance of exudates detection since, besides being important for DR detection; it also helps greatly in assessing risk of ME.

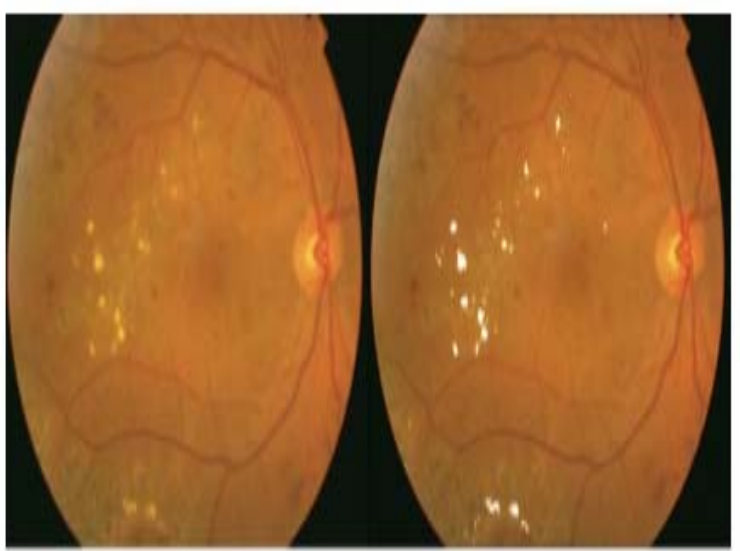

(a)

(b)

Fig:- Detection of exudates: (a) original image, (b) image with the exudates segmented. 


\subsection{Classification of DR}

Regarding classification of DR, two different approaches have emerged over the years. They may be called: full disease classifications and population screening classifications. The main differences between these classifications are their aim and complexity.

- Full disease classifications: Classifications in this category are mainly used by ophthalmologists. They are complex in nature considering a great number of levels of DR condition to cover the entire range of the illness comprehensively. The mentioned classification distinguishes a great number of DR stages grouped into two global stages of severity. The first stage, called Non-proliferative Diabetic Retinopathy (NPDR), refers to the earliest alterations caused by DR in the retina. In this stage, a person affected by DR shows symptoms in the form of microaneurysms, retinal hemorrhages, exudates and cotton wool spots. Vision loss can occur eventually in this stage as a consequence of $\mathrm{ME}$ or macular isquemia. On the other hand, the appearance of neovascularization marks the commencement of the second and relentless stage of DR called Proliferative Diabetic Retinopathy (PDR). In this stage, hemorrhages in the vitreous follow, ultimately, culminating into retinal detachment.

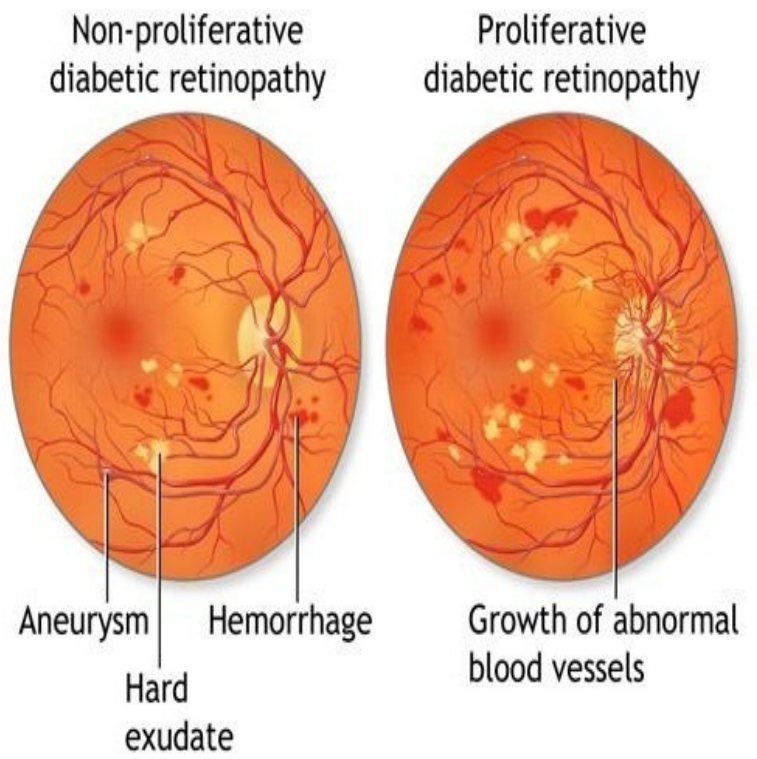

Fig:- Full disease classification

- Population screening classifications: These classifications are designed for use in large screening programs. They represent a more simplified grading based on the previous ones that allows being more efficient contextually in such programs. The main aim of these classifications is not to grade DR precisely, but to assess when a patient presents the illness in a stage sufficiently qualified in terms of severity to be referred for expert ophthalmological opinion and possible treatment. Typically, these classifications are designed by countries which then analyze their requirements to make screening programs feasible.

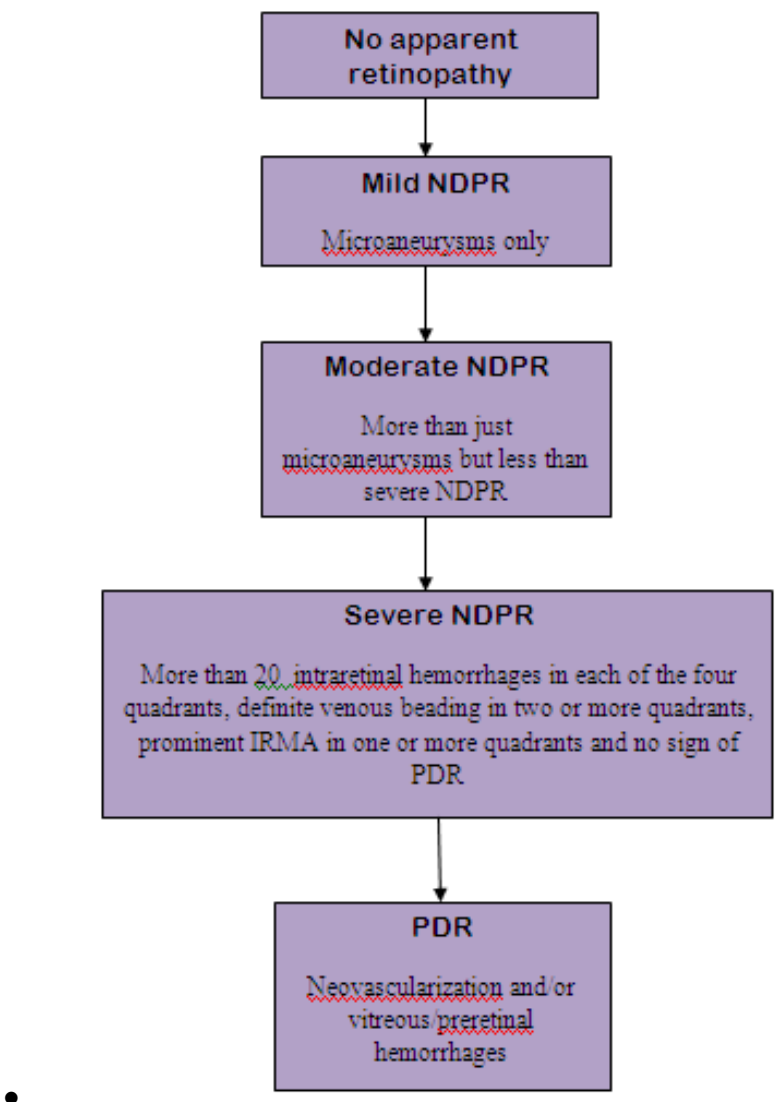

Fig:- An example of population screening classification

\section{LITERATURE REVIEW}

The existing studies and various researchers have investigated the domain of Automated diagnosis of Diabetic Retinopathy. This review, therefore, is an attempt to critically explore the literature in the area of machine learning and deep learning techniques used for DR detection culminating the process with derivation of a comparison between the two.

\subsection{Deep learning Methods}

Deep learning is a new branch of machine learning technology falling under the umbrella term of artificial intelligence. It has an ample potential for health care and may allow the identification of which patients will probable develop a particular disease further probing into and finding among those with a particular condition, which patients need to be seen more often and perhaps treated more assertively and resolution of what specific treatments may be most suitable for these patients. Diabetic retinopathy (DR) is the quickest developing and a standout amongst the most broadly spread reason for visual deficiency with almost 415 million diabetic patients in danger around the world. On the off chance that distinguished early, the ailment can be dealt with; if not, it can prompt perpetual visual deficiency. Sadly, restorative masters sufficiently skilled to recognize the sickness are not accessible in numerous parts of the world where diabetes is normal. Along these lines, Machine Learning acts the hero here and can enable specialists to recognize patients in require adequately, especially among populaces with deficient administrations. A standout amongst the most widely recognized approaches to distinguish DR is to have a pro look at photos of the back of the eye and rate them for sickness nearness and seriousness. Seriousness is controlled by the kind of sores exhibit (e.g. 
microaneurysms, hemorrhages, hard exudates, and so forth), which are demonstrative of draining and spillage of liquid in the eye. Elucidation of these photos requires specific preparing, and there are insufficient qualified graders to identify populaces in danger. Computerized DR screening strategies with high precision can gigantically help specialists in assessing more patients and rapidly distinguishing the individuals who require a referral.

1.1.1 Image understanding with deep convolutional networks: the basis of Deep learning methods for DR detection

ConvNets have been applied with remarkable success to the detection, segmentation and recognition of objects and regions in images since the early 2000s. ConvNets were largely desolated by the mainstream computer-vision and machine-learning communities until the ImageNet competition in 2012 where when deep convolutional networks were applied to a data set of about a million images from the web that contained 1,000 different classes, they achieved stunning results, almost cutting down the error rates to half as those of the best competing approaches. This success was a result of the efficient use of GPUs, ReLUs, a new regularization technique called dropout, and techniques to generate more training examples by distorting the existing ones. Hence, ConvNets established themselves as dominant approach for almost all recognition and detection tasks presently and nearly matched human performance on some tasks. Their application to DR detection has brought deep learning to limelight being more efficient and promising than all the methods previously used in the field.

\section{Fundus photograph acquisition}

2. Automated leaming procedure

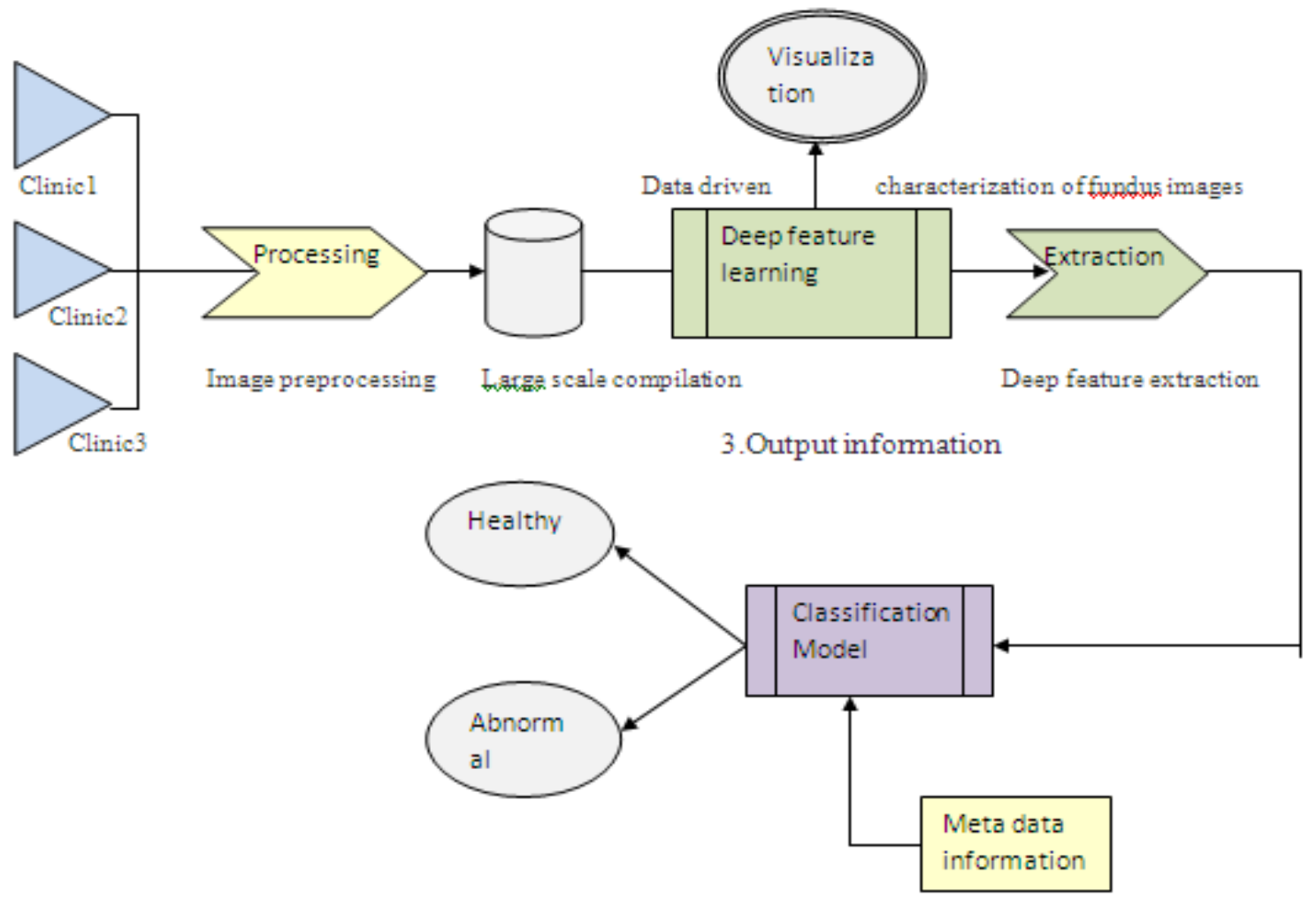

Fig:-An example of deep learning based algorithm for diabetic retinopathy detection

\section{- (Gulshan et al, 2016, Development and Validation of a Deep Learning Algorithm for Detection of Diabetic Retinopathy in Retinal Fundus Photographs)}

The given paper applied deep learning to construct an algorithm for automated detection of diabetic retinopathy along with diabetic macular edema in retinal fundus photographs. Profound convolutional neural system was utilized for picture grouping prepared utilizing a dataset of 128175 retinal pictures reviewed 3 to 7 times for diabetic retinopathy and diabetic macular edema by a board of 54 US authorized ophthalmologists and ophthalmology senior occupants amongst May and December 2015.The calculation was additionally approved in January and February 2016 utilizing 2 isolate datasets. The calculation so created had high affectability and specificity for recognizing referable diabetic retinopathy. Additionally investigate is important to decide the attainability of applying this setup in the clinical condition. [13]

- (Jen Hong Tan et al, 2017, Automated Segmentation of Exudates, Hemorrhages, Microaneurysms using Single Convolutional Neural Network)

The paper proposes to use a 10-layer convolutional neural network to automatically concurrently segment and differentiate exudates, hemorrhages and micro-aneurysms. Input images were normalized before segmentation. The net is trained in two stages to improve performance. 30,275,903 effective points in the CLEOPATRA database achieving satisfactory results although a drop in sensitivity is observed for hemorrhages and micro-aneurysms. This study shows that it is possible to get a single convolutional neural network to segment such pathological features on a wide range of fundus images with reasonable accuracy. [1] 
- (Doshi et al, 2016, Diabetic Retinopathy Detection using Deep Convolutional Neural Networks)

This paper aims at automatic diagnosis of DR into different stages using deep learning. The design and implementation of GPU accelerated deep convolutional neural networks to automatically diagnose has been presented hence classifying high-resolution retinal images into 5 stages of the disease based on severity. Three major CNN models were designed their architectures constructed and the corresponding quadratic kappa was found. The single model achieved an accuracy of 0.386 on a quadratic weighted kappa metric and ensemble of three such similar models resulted in a score of 0.3996. [4]

\section{- (Abbas et al, 2017, Automatic acknowledgment of seriousness level for conclusion of diabetic retinopathy utilizing profound visual highlights)}

In this article, a novel programmed acknowledgment framework for arranging diabetic retinopathy (SLDR) in five seriousness levels is created through learning of profound visual highlights (DVFs).However, no pre-or post handling steps were performed. Extraction of DVF highlights was done from each picture by utilizing shading thick in scale-invariant and angle area introduction histogram strategies. Learning included a semi-administered multilayer profound learning calculation alongside another compacted layer and adjusting steps. This SLDR framework was assessed and contrasted and best in class systems utilizing the measures of affectability (SE), specificity (SP) and territory under the accepting working bends (AUC).Around 750 fundus images were analyzed and highly satisfying results were obtained which demonstrated that the proposed SLDR system is appropriate for early detection of DR and provide an effective treatment for prediction type of diabetes.[3]

- (Gargeya et al, 2016, Automated Identification of Diabetic Retinopathy Using Deep Learning)

This paper presents the development followed by an evaluation of a data-driven deep learning algorithm as a diagnostic tool for automated DR detection. The calculation handled shading fundus pictures furthermore ordering them as sound (no retinopathy) or having DR, distinguishing proof of cases pertinent for medicinal referral is likewise done. An aggregate of 75137 openly accessible fundus pictures from diabetic patients were utilized to prepare and test this model to separate sound fundifrom those with DR. A board of retinal masters decided the ground truth for the given informational index before experimentation. The model was likewise tried utilizing people in general MESSIDOR 2 and E- Ophtha databases for approval reason. Representation of the data learned was finished utilizing a consequently created variation from the norm warm guide. The model accomplished satisfactory and precise outcomes. [7]

- (Grinsven, 2016, Fast convolutional neural network training using selective data sampling: Application to hemorrhage detection in color fundus images)

The proposed method provides an improvement and speedup of the CNN trained for medical image analysis tasks by dynamically selecting misclassified negative samples. Heuristic testing of preparing tests is done in light of grouping by the present status of the CNN. Weights are then doled out to the preparation tests. A correlation has likewise been performed between the two i.e., $\mathrm{CNN}$ with $(\mathrm{SeS})$ and without (NSeS) the particular examining technique. Spotlight is on the identification of hemorrhages in shading fundus pictures. Execution was enhanced and attractive and an equivalent zone under bend trademark was acheived on two informational collections. Be that as it may, the SeS CNN factually beat the NSeS CNN on a free test set. [2]

- (Quellec et al, 2017, Deep Image Mining for Diabetic Retinopathy Screening)

Here, a generalization of the backpropagation method is proposed in order to train ConvNets that produce highquality heatmaps. The proposed arrangement is connected to diabetic retinopathy (DR) screening in a dataset of just about 90,000 fundus photos from the 2015 Kaggle Diabetic Retinopathy rivalry and a private dataset of very nearly 110,000 photos (e-ophtha). For the undertaking of recognizing referable DR, great location execution was accomplished. Execution was likewise assessed at the picture level and at the sore level in the DiaretDB1 dataset, where the proposed locator prepared to identify referable DR outflanks late calculations prepared to recognize those sores especially, with pixel-level supervision. At the sore level, the proposed identifier beats heatmap age calculations for ConvNets. [5]

- (Pratt et al, 2016, Convolutional Neural Networks for Diabetic Retinopathy)

In this paper, $\mathrm{CNN}$ approach is proposed to diagnosing DR from digital fundus images along with accurate classification of its severity. A connect with CNN engineering and information expansion is produced which distinguishes highlights, for example, smaller scale aneurysms, exudate and hemorrhages on the retina engaged with the order errand and as a result give a determination naturally without client input. To prepare this system, a top of the line illustrations processor unit (GPU) is utilized on the freely accessible Kaggle dataset with 80,000 pictures which showed amazing outcomes, especially for an abnormal state arrangement assignment. Moreover, 5000 images wre used for validation which also presented suitable results.[6]

- (Colas E, 2016, Deep learning approach for diabetic retinopathy screening)

The proposed method called DreamUp Vision uses state-of the art technology based on deep-learning. The given algorithm was trained on over 70,000 labeled retinal images. Images were graded by ophthalmologists as follows: 0 (no retinopathy), 1 (mild non proliferative DR), 2 (moderate non proliferative DR), 3 (severe non proliferative DR) and 4 (proliferative retinopathy). Both left and right eye representation was used. Grading is done for each eye image separately. The algorithm performed quick and reliable detection of irregularities in retinal images, diagnosed their stage of diabetic retinopathy and provided the location of the anomalies detected in the pictures. A patient was considered as referable if the DR stage is between 2 and 4 and nonreferable otherwise. The model is evaluated on over 10,000 fundus images from 5,000 patients taken from the Kaggle DR Detection Challenge dataset, provided by California Healthcare Foundation. [8]

- (Roy et al, 2017, A novel hybrid approach for severity assessment of diabetic retinopathy in colour fundus images) 
In this paper, proposal is to combine CNNs with dictionary based approaches, which integrates pathology specific image representation into the learning framework for an improved classification of DR severity. Both specific and generative pathology histograms were constructed and combined with feature representations extracted from fully connected CNN layers. The results indicated that the proposed method showed noticeable improvement in quadratic kappa score. [9]

\section{- (Paul et al, 2016, Heterogeneous Modular Deep}

Neural Network for Diabetic Retinopathy Detection)

This paper proposes heterogeneous modular deep neural network (DNN) to detect diabetic retinopathy along with the five types of abnormalities. The modular approach gives the advantage to extract class specific features for the classifier, hence, outperforming the classical convolutional neural networks. Moreover, the heterogeneous nature of modular DNN ensures economy of scale in the overall architecture and also provides for extraction of region specific features which further contribute to higher accuracy of detection. The benchmark dataset was used for performing extensive simulation studies and results showed that the proposed approach performs better or at par with other standard approaches. [10]

- (Takahashi et al, 2017, Applying artificial intelligence to disease staging: Deep learning for improved staging of diabetic retinopathy)

The retrospective study analyzed 9,939 posterior pole photographs of 2,740 patients with diabetes. Non-mydriatic $45^{\circ}$ field shading fundus photos were taken of four fields in each eye every year at Jichi Medical University between May 2011 and June 2015. An altered completely haphazardly instated GoogLeNet profound learning neural system was prepared on $95 \%$ of the photos utilizing manual changed Davis evaluating of three extra nearby photos. The evaluating of 4,709 of the 9,939 back shaft fundus photos was finished utilizing genuine forecasts. Furthermore, 95\% of the photos were learned by the altered GoogLeNet. Fundamental result measures were pervasiveness and predisposition balanced Fleiss' kappa (PABAK) of AI arranging of the rest of the $5 \%$ of the photos. [11]

- (Eltanboly et al, 2016, A PC helped demonstrative framework for identifying diabetic retinopathy in optical lucidness tomography pictures)

The proposed PC helped demonstrative (CAD) framework for identifying diabetic retinopathy (DR) varies from above expressed strategies as it joins novel and productive division and arrangement procedures on optical lucidness tomography (OCT) pictures of the retina. After segmenting 12 distinct retinal layers, three quantitative features (pixelwise curvature, reflectivity and thickness) are extracted each over an own layer showing statistically significant differences of values between normal and diabetic subjects. of the proposed PC helped demonstrative framework for early DR location utilizing the OCT retinal pictures. [12]

\section{- (Prentasic et al, 2016, Detection of exudates in} fundus photos utilizing profound neural systems and anatomical historic point location combination)

Aggregate appropriation elements of these highlights are examined by a two-organize trainable profound combination arrangement arrange (DFCN) with heaps of non-cynicism compelled autoencoders (SNCAE) to decide if the subject has DR or not. Both the quantitative and visual evaluations affirmed the high precision. Profound convolutional neural systems have been utilized for exudate recognition.In order to integrate high level anatomical knowledge about potential exudate locations, output of the convolutional neural network is combined with the output of the optic disc detection and vessel detection procedures. In the validation step using a manually segmented image database, a maximum F1 measure of 0.78 was obtained. This, therefore, has been proven to be an important step in creating automated screening programs for early detection of diabetic retinopathy. [14]

- (Prentasic et al, 2015, Detection of Exudates in Fundus Photographs using Convolutional Neural Networks)

In this paper it is shown that deep convolutional neural networks can be effectively used in order to segment exudates in color fundus photographs. However, the final segmentation result would certainly improve by enhancing the network by using all the available channels and adding some preprocessing and post processing steps because grouping detected pixels in clusters and adding some high level features. [15]

- (Shan et al, 2016, A deep learning method for microaneurysm detection in fundus images)

In this paper, a two layered stacked space auto-encoder framework is given for automatic MA detection on fundus images. The SSAE model can capture high level features from pixel level input in an unsupervised learning method. These high level features provides efficiency to the SMC classifier and enable it to detect MA lesions from fundus images with complicated background. The performance before and after fine tuning were compared and it was seen that the fine tuning proved to be helpful in boosting the performance of the patch classification. [16]

- (Holly H. Vo et al, 2016, New Deep Neural Nets for Fine-Grained Diabetic Retinopathy Recognition on Hybrid Color Space)

In this paper, the part of various filter sizes in learning finegrained discriminant highlights is underscored henceforth proposing two profound convolutional neural systems Combined Kernels with Multiple Losses Network (CKML Net) and VGGNet with Extra Kernel (VNXK), which are a change upon GoogLeNet and VGGNet in setting of DR assignments. Likewise, half and half shading space, LGI, for DR acknowledgment is proposed and finally, exchange learning is connected to take care of the issue of imbalanced dataset. The adequacy of proposed framework is assessed utilizing two thousand test retina datasets: EyePACS and Messidor. [18]

- $\quad$ (Costa et al, 2017, Convolutional Bag of Words for Diabetic Retinopathy Detection from Eye Fundus Images)

This paper depicts a strategy for Diabetic Retinopathy recognition from eye fundus pictures utilizing a speculation of the Bag-of-Visual-Words (BoVW) technique. The definition of the BoVW includes two neural systems that can be prepared together. Not at all like the BoVW, the proposed show can figure out how to perform include extraction, highlight encoding and order through the grouping blunder. The model accomplishes an enhanced Area Under the Curve (AUC) on the DR2 and Messidor datasets when contrasted with the standard BoVW approach. [17] 


\begin{tabular}{|c|c|c|c|c|c|c|}
\hline AUTHOR(year) & $\begin{array}{c}\text { Journal/Co } \\
\text { nference } \\
\text { Title } \\
\end{array}$ & DATASET & PURPOSE & METHODS & $\begin{array}{l}\text { RESULTS } \\
\text { (parameters) }\end{array}$ & LIMITATIONS \\
\hline \multicolumn{7}{|c|}{ BASED ON DEEP LEARNING TECHNIQUES } \\
\hline $\begin{array}{l}\text { Prentasic, pavle } \\
\text { et al (2015), } \\
{[15]}\end{array}$ & $\begin{array}{l}\text { 9th } \\
\text { International } \\
\text { Symposium } \\
\text { on Image } \\
\text { and Signal } \\
\text { Processing } \\
\text { and Analysis } \\
\text { (ISPA } \\
\text { 2015), IEEE }\end{array}$ & DRiDB & $\begin{array}{l}\text { Detection of } \\
\text { exudates in } \\
\text { fundus images } \\
\text { using CNN for } \\
\text { early diagnosis } \\
\text { of DR }\end{array}$ & $\begin{array}{l}\text { Deep neural } \\
\text { networks or } \\
\text { CNNs }\end{array}$ & $\begin{array}{l}\text { Sensitivity }=0.7 \\
7 \mathrm{ppv}=0.77, \mathrm{f}- \\
\text { score }=0.77\end{array}$ & $\begin{array}{l}\text { Database is small, final } \\
\text { segmentation could be } \\
\text { improved }\end{array}$ \\
\hline $\begin{array}{l}\text { Pratt, et } \\
\text { al(2016), [6] }\end{array}$ & $\begin{array}{l}\text { International } \\
\text { Conference } \\
\text { On Medical } \\
\text { Imaging } \\
\text { Understandi } \\
\text { ng and } \\
\text { Analysis } \\
2016\end{array}$ & Kaggle & $\begin{array}{l}\text { Diagnose DR } \\
\text { from digital } \\
\text { fundus images } \\
\text { and classying } \\
\text { its severity }\end{array}$ & $\begin{array}{l}\text { Network with } \\
\text { CNN } \\
\text { architecture } \\
\text { and data } \\
\text { augmentation }\end{array}$ & $\begin{array}{l}\text { Sensitivity }=95 \\
\%, \\
\text { accuracy }=75 \%\end{array}$ & $\begin{array}{l}\text { Hard to distinguish } \mathrm{b} / \mathrm{w} \text { mild, } \\
\text { moderate and severe cases of } \\
\text { DR along with low sensitivity } \\
\text { in mild and moderate cases }\end{array}$ \\
\hline $\begin{array}{l}\text { Doshi, et } \\
\text { al(2016), [4] }\end{array}$ & $\begin{array}{l}2016 \\
\text { International } \\
\text { Conference } \\
\text { on } \\
\text { Computing, } \\
\text { Analytics } \\
\text { and Security } \\
\text { Trends } \\
\text { (CAST), } \\
\text { IEEE }\end{array}$ & EyePACS & $\begin{array}{l}\text { DR detection } \\
\text { using deep } \\
\text { CNNs }\end{array}$ & $\begin{array}{l}\text { Deep CNN } \\
\text { design, } \\
\text { architecture } \\
\text { and } \\
\text { implementatio } \\
\mathrm{n} \text { for DR } \\
\text { detection and } \\
\text { quadratic } \\
\text { kappa metric } \\
\text { for evaluation }\end{array}$ & $\begin{array}{l}\text { Accuracy }=0.3 \\
86 \text { using single } \\
\text { model and } \\
\text { accuracy }=0.39 \\
96 \text { using } \\
\text { ensemble of } 3 \\
\text { models }\end{array}$ & $\begin{array}{l}\text { Using all the channels instead } \\
\text { of a single channel to decrease } \\
\text { over-fitting, to improve noise } \\
\text { reduction, accuracy can be } \\
\text { improved }\end{array}$ \\
\hline $\begin{array}{l}\text { Prentasic, et } \\
\text { al(2016 } \\
\text { accepted } \\
\text { article), [14] }\end{array}$ & $\begin{array}{l}\text { Computer } \\
\text { Methods and } \\
\text { Programs in } \\
\text { Biomedicine } \\
\text {, Elsevier }\end{array}$ & DRiDB & $\begin{array}{l}\text { automated } \\
\text { segmentation } \\
\text { using CNN in } \\
\text { combination } \\
\text { with other } \\
\text { landmark } \\
\text { detectors for } \\
\text { early detection } \\
\text { of DR }\end{array}$ & $\begin{array}{l}\text { CNN in } \\
\text { combination } \\
\text { with optic disc } \\
\text { detection and } \\
\text { vessel } \\
\text { detection } \\
\text { procedure. }\end{array}$ & $\begin{array}{l}\text { F-measure } \\
=0.78\end{array}$ & $\begin{array}{l}\text { final segmentation could be } \\
\text { improved, grouping detected } \\
\text { pixels in clusters, using all } \\
\text { channels }\end{array}$ \\
\hline $\begin{array}{l}\text { Shan et } \\
\text { al(2016), [16] }\end{array}$ & $\begin{array}{l}2015 \text { IEEE } \\
\text { First } \\
\text { Conference } \\
\text { on } \\
\text { Connected } \\
\text { Health: } \\
\text { Applications } \\
\text {, Systems } \\
\text { and } \\
\text { Engineering } \\
\text { Technologie } \\
\text { s }\end{array}$ & DiaretDB & $\begin{array}{l}\text { Detection of } \\
\text { microaneurys } \\
\text { ms for early } \\
\text { detection of } \\
\text { DR }\end{array}$ & $\begin{array}{l}\text { 2-layered } \\
\text { stacked sparse } \\
\text { autoencoder } \\
\text { framework }\end{array}$ & $\begin{array}{l}\mathrm{f}- \\
\text { measure }=91.3 \\
\% \\
\text { AUC }=96.2 \%\end{array}$ & $\begin{array}{l}\text { Database is small, scope for } \\
\text { improvement in } \\
\text { characterization of MA lesions }\end{array}$ \\
\hline $\begin{array}{l}\text { Colas .E } \\
(2016),[8]\end{array}$ & $\begin{array}{l}\text { Wiley } \\
\text { Online } \\
\text { Library }\end{array}$ & Kaggle & $\begin{array}{l}\text { Deep learning } \\
\text { approach for } \\
\text { DR screening }\end{array}$ & $\begin{array}{l}\text { DreamUp } \\
\text { Vision }\end{array}$ & $\begin{array}{l}\text { AUROC }=0.94 \\
6, \\
\text { sensitivity }=96 . \\
2 \%, \\
\text { specificity }=66 . \\
6 \%\end{array}$ & $\begin{array}{l}\text { Scope for performance } \\
\text { improvement }\end{array}$ \\
\hline
\end{tabular}




\begin{tabular}{|c|c|c|c|c|c|c|}
\hline $\begin{array}{l}\text { Gulshan et } \\
\text { al(2016), [13] }\end{array}$ & $\begin{array}{l}\text { Journal of } \\
\text { American } \\
\text { Medical } \\
\text { association }\end{array}$ & $\begin{array}{l}\text { EyePACS, } \\
\text { MESSIDOR }\end{array}$ & $\begin{array}{l}\text { Development } \\
\text { and Validation } \\
\text { of a Deep } \\
\text { Learning } \\
\text { Algorithm for } \\
\text { Detection of } \\
\text { DR in Retinal } \\
\text { Fundus Images }\end{array}$ & $\begin{array}{l}\text { Deep } \\
\text { Convolutional } \\
\text { Neural } \\
\text { Network }\end{array}$ & $\begin{array}{l}\text { For Messidor2, } \\
\text { sensitivity=87. } \\
0 \% \text { and } \\
\text { specificity=98. } \\
5 \% \\
\text { For EyePACS- } \\
1, \\
\text { sensitivity=90. } \\
3 \% \text { and } \\
\text { specificity } \\
=98.1 \%\end{array}$ & $\begin{array}{l}\text { Feasibility of the method is } \\
\text { doubted }\end{array}$ \\
\hline $\begin{array}{l}\text { Eltanboly et al, } \\
2016 \\
\text { ( article in } \\
\text { press), [12] }\end{array}$ & $\begin{array}{l}\text { Journal of } \\
\text { Medical } \\
\text { physics }\end{array}$ & $\begin{array}{l}\text { Private } \\
\text { dataset }\end{array}$ & $\begin{array}{l}\text { CAD system } \\
\text { for detecting } \\
\text { DR on OCT } \\
\text { images }\end{array}$ & $\begin{array}{l}\text { Segmentation } \\
\text { and } \\
\text { classification } \\
\text { using DFCN } \\
\text { and SNCAE }\end{array}$ & $\begin{array}{l}\text { Accuracy }=92 \\
\%, \\
\text { sensitivity }=83 \\
\%, \\
\text { specificity }=10 \\
0 \%\end{array}$ & Database is small \\
\hline $\begin{array}{l}\text { Soniya, paul } \\
\text { Sandeep, Lotika } \\
\text { singh(2016), } \\
{[10]}\end{array}$ & $\begin{array}{l}\text { Humanitaria } \\
\mathrm{n} \\
\text { Technology } \\
\text { Conference } \\
\text { (R10-HTC), } \\
\text { 2016 IEEE } \\
\text { Region } 10\end{array}$ & DIARETDB0 & $\begin{array}{l}\text { Detection of } \\
\text { DR and } \\
\text { simultaneously } \\
\text { the five types } \\
\text { of } \\
\text { abnormalities }\end{array}$ & $\begin{array}{l}\text { Heterogeneous } \\
\text { Modular Deep } \\
\text { Neural } \\
\text { Network }\end{array}$ & $\begin{array}{l}\text { Different } \\
\text { accuracy, } \\
\text { sensitivity and } \\
\text { specificity } \\
\text { reading for all } \\
\text { five } \\
\text { abnormalities }\end{array}$ & $\begin{array}{l}\text { Powerful classifiers working } \\
\text { on complex datasets can be } \\
\text { used }\end{array}$ \\
\hline $\begin{array}{l}\text { Holly H. Vo, } \\
\text { Abhishek } \\
\text { Verma(2016), } \\
{[18]}\end{array}$ & $\begin{array}{l}2016 \text { IEEE } \\
\text { International } \\
\text { Symposium } \\
\text { on } \\
\text { Multimedia }\end{array}$ & $\begin{array}{l}\text { EyePACS } \\
\text { and } \\
\text { Messidor( } \\
\text { around } 450 \\
\text { images) }\end{array}$ & $\begin{array}{l}\text { New Deep } \\
\text { Neural Nets } \\
\text { for Fine- } \\
\text { Grained } \\
\text { Diabetic } \\
\text { Retinopathy } \\
\text { Recognition } \\
\text { on Hybrid } \\
\text { Color Space }\end{array}$ & $\begin{array}{l}\text { two deep } \\
\text { convolutional } \\
\text { neural } \\
\text { networks - } \\
\text { CKML Net } \\
\text { and VGGNet } \\
\text { with Extra } \\
\text { Kernel } \\
\text { (VNXK), a } \\
\text { hybrid color } \\
\text { space, LGI, for } \\
\text { DR } \\
\text { recognition via } \\
\text { proposed nets } \\
\text { and Transfer } \\
\text { learning to } \\
\text { solve the } \\
\text { challenge of } \\
\text { imbalanced } \\
\text { dataset. }\end{array}$ & $\begin{array}{l}\text { Normal/ } \\
\text { Abnormal } \\
\text { CKML } \\
\text { Net/LGI(ROC, } \\
\text { Sns., Spec., } \\
\text { Acc.) 0.862, } \\
\text { 0.916, 0.803, } \\
\text { 0.858) and } \\
\text { VNXK/LGI } \\
0.8700 .882 \\
0.8570 .871 \\
\text { Referable/ } \\
\text { Non-referable } \\
\text { CKML } \\
\text { Net/LGI } 0.891 \\
0.8930 .900 \\
0.897 \\
\text { VNXK/LGI } \\
0.8870 .900 \\
0.8920 .893\end{array}$ & $\begin{array}{l}\text { Other techniques such as cost- } \\
\text { sensitive and kernel-based } \\
\text { classifiers that could be } \\
\text { combined with transfer } \\
\text { learning to further boost the } \\
\text { performance of proposed } \\
\text { current methodology, the } \\
\text { dataset used is also } \\
\text { comparatively small }\end{array}$ \\
\hline $\begin{array}{l}\text { Quellec, et } \\
\text { al(2017), [5] }\end{array}$ & $\begin{array}{l}\text { Medical } \\
\text { Image } \\
\text { Analysis, } \\
\text { Elsevier }\end{array}$ & $\begin{array}{l}\text { Kaggle, e- } \\
\text { ophtha, } \\
\text { MESSIDOR, } \\
\text { DiaretDB1 }\end{array}$ & $\begin{array}{l}\text { Automatic } \\
\text { detection of } \\
\text { referable DR } \\
\text { and automatic } \\
\text { detection of } \\
\text { lesions related } \\
\text { to DR }\end{array}$ & $\begin{array}{l}\text { Convnet, Heat } \\
\text { maps and back } \\
\text { propagation } \\
\text { algorithm for } \\
\text { training }\end{array}$ & $\begin{array}{l}\mathrm{Az}=0.954 \text { in } \\
\text { Kaggle, } \\
\mathrm{Az}=0.949 \text { in e- } \\
\text { ophtha }\end{array}$ & $\begin{array}{l}\text { Only referable DR cases i.e., } \\
\text { above moderate is considered }\end{array}$ \\
\hline $\begin{array}{l}\text { Gargeya, et } \\
\operatorname{al}(2017),[7]\end{array}$ & $\begin{array}{l}\text { American } \\
\text { Academy of } \\
\text { Ophthamolo } \\
\text { gy }\end{array}$ & $\begin{array}{l}\text { EyePACS, } \\
\text { MESSIDOR, } \\
\text { e-ophtha }\end{array}$ & $\begin{array}{l}\text { Developing a } \\
\text { diagnostic } \\
\text { technology to } \\
\text { automate DR } \\
\text { screening }\end{array}$ & $\begin{array}{l}\text { Automated } \\
\text { feature } \\
\text { learning } \\
\text { approach to } \\
\text { DR detection } \\
\text { using deep } \\
\text { learning } \\
\text { methods }\end{array}$ & $\begin{array}{l}\text { Sensitivity }=94 \\
\% \text {, } \\
\text { specificity }=98 \\
\%, \text { AUC }=0.97\end{array}$ & $\begin{array}{l}\text { Difficulty in microaneurysms } \\
\text { detection }\end{array}$ \\
\hline $\begin{array}{l}\text { Grinsven, Mark } \\
\text { J. J. P. van et al } \\
\text { (article in }\end{array}$ & $\begin{array}{l}\text { IEEE } \\
\text { Transactions } \\
\text { on Medical }\end{array}$ & $\begin{array}{l}\text { Kaggle, } \\
\text { MESSIDOR }\end{array}$ & $\begin{array}{l}\text { Hemorrhage } \\
\text { detection in } \\
\text { color fundus }\end{array}$ & SeS CNN & $\begin{array}{l}\text { Epoch }=60, \\
\text { Sensitivity }=0.7 \\
86 \text { for false }\end{array}$ & $\begin{array}{l}\text { Increased database size can } \\
\text { improve performance }\end{array}$ \\
\hline
\end{tabular}




\begin{tabular}{|c|c|c|c|c|c|c|}
\hline $\begin{array}{l}\text { press)(2017), } \\
{[1]}\end{array}$ & Imaging & & $\begin{array}{l}\text { images using } \\
\text { Fast CNN with } \\
\text { selective data } \\
\text { sampling }\end{array}$ & & $\begin{array}{l}\text { positive }=1, \\
\text { Sensitivity }= \\
0.511 \text { for false } \\
\text { positive }=0.1\end{array}$ & \\
\hline $\begin{array}{l}\text { Costa, Pedro et } \\
\text { al(2017), [17] }\end{array}$ & $\begin{array}{l}2017 \\
\text { Fifteenth } \\
\text { IAPR } \\
\text { International } \\
\text { Conference } \\
\text { on Machine } \\
\text { Vision } \\
\text { Applications } \\
\text { (MVA) } \\
\end{array}$ & $\begin{array}{l}\text { DR1, DR2, } \\
\text { Messidor }\end{array}$ & $\begin{array}{l}\text { Diabetic } \\
\text { Retinopathy } \\
\text { detection from } \\
\text { eye fundus } \\
\text { images }\end{array}$ & $\begin{array}{l}\text { generalization } \\
\text { of the Bag-of- } \\
\text { Visual-Words } \\
\text { (BoVW) } \\
\text { method, CNN } \\
\text { used as } \\
\text { classifier }\end{array}$ & $\begin{array}{l}\text { AUC }=0.97 \text { for } \\
\text { DR2, } \\
\text { AUC }=0.90 \text { for } \\
\text { MESSIDOR }\end{array}$ & $\begin{array}{l}\text { using a CNN to extract } \\
\text { features did'nt work well with } \\
\text { one dataset, evaluation of } \\
\text { interpretability is missing }\end{array}$ \\
\hline $\begin{array}{l}\text { Roy, pallab, } \\
\text { Khoa } \\
\text { Cao(2017), [9] }\end{array}$ & $\begin{array}{l}2017 \text { IEEE } \\
\text { 14th } \\
\text { International } \\
\text { Symposium } \\
\text { on } \\
\text { Biomedical } \\
\text { Imaging } \\
\text { (ISBI 2017) } \\
\end{array}$ & EyePACS & $\begin{array}{l}\text { Severity } \\
\text { assessment of } \\
\text { diabetic } \\
\text { retinopathy in } \\
\text { colour } \\
\text { fundus images }\end{array}$ & $\begin{array}{l}\text { CNNs } \\
\text { combined with } \\
\text { dictionary } \\
\text { based } \\
\text { approaches }\end{array}$ & $\begin{array}{l}\text { Quadratic } \\
\text { kappa score }(\kappa 2 \\
=0.86)\end{array}$ & $\begin{array}{l}\text { Less usability for early } \\
\text { detection of DR i.e., mild } \\
\text { cases with microaneurysms }\end{array}$ \\
\hline $\begin{array}{l}\text { Jen Hong Tan, } \\
\text { Hamido Fujita, } \\
\text { A. Krishna Rao } \\
\text {, Kuang Chua } \\
\text { Chua, U. } \\
\text { Rajendra } \\
\text { Acharya(article } \\
\text { in press 2017), } \\
\text { [1] }\end{array}$ & $\begin{array}{l}\text { Information } \\
\text { Sciences, } \\
\text { Elsevier }\end{array}$ & $\begin{array}{l}\text { CLEOPATR } \\
\text { A(149 for } \\
\text { training and } \\
149 \text { for } \\
\text { testing) }\end{array}$ & $\begin{array}{l}\text { Automated } \\
\text { segmentation } \\
\text { of exudates, } \\
\text { haemorrhages } \\
\text { and micro- } \\
\text { aneurysms }\end{array}$ & $\begin{array}{l}\text { 10-layer } \\
\text { convolutional } \\
\text { neural network } \\
\text { is employed }\end{array}$ & $\begin{array}{l}\text { sensitivity of } \\
0.8758 \text { and } \\
0.7158 \text { for } \\
\text { exudates and } \\
\text { dark lesions } \\
\text { respectively }\end{array}$ & $\begin{array}{l}\text { sensitivities of the } \\
\text { segmentation on hemorrhages } \\
\text { and micro-aneurysms can be } \\
\text { further improved, also dataset } \\
\text { size is small }\end{array}$ \\
\hline $\begin{array}{l}\text { Takahashi } \\
\text { hidenori et } \\
\text { al(2017), [11] }\end{array}$ & $\begin{array}{l}\text { PLOS ONE } \\
\text { Journal }\end{array}$ & $\begin{array}{l}\text { Private } \\
\text { dataset }\end{array}$ & $\begin{array}{l}\text { Improvement } \\
\text { in staging of } \\
\text { DR using deep } \\
\text { learning }\end{array}$ & $\begin{array}{l}\text { AI disease- } \\
\text { staging system } \\
\text { for grading DR } \\
\text { that involves a } \\
\text { retinal area not } \\
\text { typically } \\
\text { visualized on } \\
\text { fundoscopy } \\
\text { and another AI } \\
\text { that directly } \\
\text { suggests } \\
\text { treatments and } \\
\text { determines } \\
\text { prognoses. }\end{array}$ & $\begin{array}{l}\text { accuracy, } 81 \% \\
\text { in grading } \\
\text { accuracy, } 96 \% \\
\text { in real } \\
\text { prognosis }\end{array}$ & $\begin{array}{l}\text { Noticeable false negative } \\
\text { rates, only one field fundus } \\
\text { photography used }\end{array}$ \\
\hline $\begin{array}{l}\text { Qaisar Abbas, } \\
\text { Irene Fondon, } \\
\text { Auxiliadora } \\
\text { Sarmiento, } \\
\text { Soledad } \\
\text { Jiménez, Pedro } \\
\text { Alemany(2017), } \\
\text { [3] }\end{array}$ & $\begin{array}{l}\text { Medical and } \\
\text { Biological } \\
\text { Engineering } \\
2017 \text {, } \\
\text { Springer }\end{array}$ & $\begin{array}{l}\text { DIARETDB1 } \\
\text { MESSIDOR, } \\
\text { FAV, Prv- } \\
\text { DR(750) }\end{array}$ & $\begin{array}{l}\text { Automatic } \\
\text { recognition of } \\
\text { severity level } \\
\text { for diagnosis } \\
\text { of diabetic } \\
\text { retinopathy }\end{array}$ & $\begin{array}{l}\text { Computer- } \\
\text { aided } \\
\text { diagnosis, } \\
\text { Deep learning, } \\
\text { Gradient } \\
\text { location } \\
\text { orientation } \\
\text { histogram }\end{array}$ & $\begin{array}{l}\text { SE of } 92.18 \% \text {, } \\
\text { SP of } 94.50 \% \\
\text { and AUC of } \\
0.924\end{array}$ & $\begin{array}{l}\text { Overcome the evaluation of } \\
\text { diabetic maculopathy and the } \\
\text { use of more than one image } \\
\text { for classification. }\end{array}$ \\
\hline
\end{tabular}

\subsection{Machine Learning Methods}

The various machine learning methodologies prevalent in the field of DR detection are reviewed as follows:-

- Neural Networks are the learning algorithms that imitate human brain. They are a type of classification algorithm that can classify an example into multiple classes. A multi-layer neural system includes the principal layer called the info layer and the last layer called the yield layer and a few other in the middle of layers known as the concealed layers. Each layer has units called the simulated neurons and the sigmoid enactment work which is utilized to initiate these units. In between any two layers a parameter matrix is used which performs functional mapping from previous layer to next layer. Forward propagation and backward propagation are used to train the neural network.

- Support Vector Machines are the classification algorithms that are used to classify the examples when a considerably large number of features are encountered. Sometimes, SVM gives better non-linear hypothesis 
than the logistic regression and the neural networks. SVMs are also known as large margin classifiers.

- Ensemble learning is the procedure by which various models, for example, classifiers or specialists, are deliberately created and consolidated to propose an answer for a specific computational knowledge issue. Gathering learning is essentially used to enhance the (arrangement, expectation, work estimate, and so forth.) execution of a model, or diminish the possibility of unfortunately choosing a poor model. Different uses of outfit learning incorporate doling out a certainty to the choice made by the model, choosing ideal (or close ideal) highlights, information combination, incremental learning, dynamic learning and blunder revising.

- The pack of-words show is a rearranged portrayal utilized as a part of normal dialect handling and data recovery (IR). In this model, a content, (for example, a sentence or a report) is spoken to as the pack (multi-set) of its words, overlooking language structure and even the request of the words yet protecting assortment. The sack of-words show has additionally been utilized for PC vision. The sack of-words display is normally utilized as a part of techniques for grouping of the archives where classifier is prepared with highlights considering the recurrence of event if the words.

- $\quad$ Fuzzy image processing: Fuzzy set theory and fuzzy logic provide powerful tools to represent and process human knowledge in the form of fuzzy if-then rules. Many problems arise in image processing because the data, tasks, and results are vague. This ambiguity, however, is not always due to the randomness but to the inherent uncertainty of image data. Besides randomness (which is manageable to certain extent by probability theory) various other imperfections in image processing include grayness ambiguity, geometrical fuzziness, and vague knowledge of image features which also add to the difficulties faced in image processing field.

- K-nearest-neighbor (KNN) classification is one of the most basic and simple classification methods and should be considered as one of the first choices for a classification study when there is little or no prior knowledge about data distribution. K-nearest-neighbor classification was developed from the need to perform discerning analysis when reliable estimates of parameters of probability densities are not known or are hard to determine.

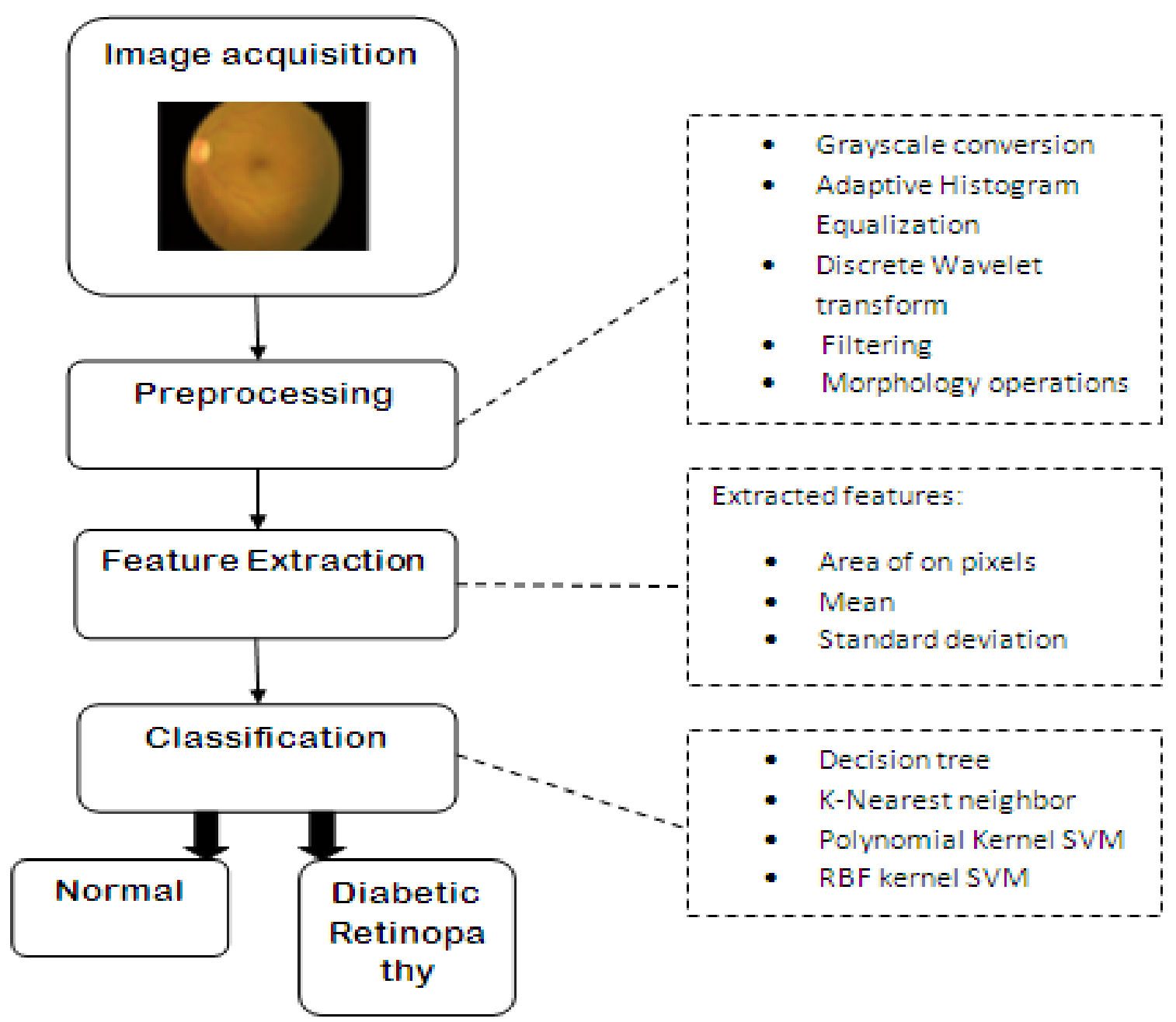

Fig:-An example of machine learning based algorithm for diabetic retinopathy detection 
- (Mahendran et al, 2015, Investigation of the severity level of diabetic retinopathy using supervised classifier algorithms)

Proposed method detects lesion exudates automatically with the aid of a non-dilated retinal fundus images to aid in diagnosis of the disease. The exudates from the low complexity pictures are distinguished and restricted utilizing an area based division system. The help vector machine (SVM) and probabilistic neural system (PNN) classifiers are utilized to evaluate the seriousness of the ailment, and the outcomes are contrasted and a similar division method.The average classification accuracy for both the SVM and PNN classifiers is sufficiently high and comparable.[34]

\section{- (Mamilla et al, 2016, Extraction of Microaneurysms} and Hemorrhages from Digital Retinal Images)

This paper presents a novel hybrid red lesion detection system that unites phase congruency based and mathematical morphology based methods to detect candidate red lesions. The paper contributes altogether in the calculation of stage congruency utilizing expanded 2D log Gabor channel. The proposed red injury identification framework is a three phase framework which joins polynomial complexity upgrade for preprocessing, half and half discovery for coarse applicant red sore extraction, and bolster vector machine classifier for fine division of red injuries. [27]

- (Ganesan et al, 2014, Computer?aided diabetic retinopathy detection using trace transforms on digital fundus images)

In this study, trace transforms were used to model a human visual system which imitates the way a human being observes an image. To order includes extricated utilizing this procedure, bolster vector machine (SVM) was utilized with quadratic, polynomial, outspread premise work bits and probabilistic neural system (Pnn). Hereditary calculation (ga) was utilized to calibrate order parameters. A whooping high precision of over $99 \%$ was gotten with both Pnn- ga and SVM quadratic portions. [24]

- (Manuel E. Gegundez-Arias et al, 2017, A tool for automated diabetic retinopathy pre-screening based on retinal image computer analysis)

This paper presents a methodology of an automatic detection system of early signs of Diabetic Retinopathy (DR) in fundus images. The framework recognizes the nearness of microaneurysms and hemorrhages in retinopathy by methods for procedures of advanced picture preparing and administered grouping. Assessment was directed on 1058 pictures of 529 diabetic patients in danger of introducing confirmation of DR (a picture of each eye is given). Additionally, a ground-truth determination in light of degrees performed by 3 autonomous ophthalmology experts was made. The comparison between the diagnosis provided nearly same sensitivities, however, the specificity of the system is significantly lower than that of human graders. [35]

- (Zhou et al, 2017, Automatic Microaneurysm Detection Using the Sparse Principal Component Analysis-Based Unsupervised Classification Method)
In this paper, a novel unsupervised classification method based on sparse posterior cerebral artery (PCA) for MA detection is presented. Here, the class imbalance problem has been avoided since non-MA training set is not considered. Furthermore, effective features can be selected due to the characteristic of sparse PCA, which combines the elastic net penalty with the PCA. Meanwhile, a single T2 statistic is introduced, and the control limit can be determined for distinguishing true MAs from spurious candidates automatically. Experiment was performed on the retinopathy online challenge competition database with results showing the effectiveness of the proposed method. [32]

\section{- (Antal et al, 2012, An Ensemble-Based System for Microaneurysm Detection and Diabetic Retinopathy Grading)}

The paper proposes an ensemble-based framework to improve microaneurysm detection. Rather than thinking about the yield of numerous classifiers, a blend of inside parts of microaneurysm identifiers, specifically preprocessing techniques and hopeful extractors is utilized here. The approach was assessed for microaneurysm identification in an online rivalry and furthermore on two different databases. Since microaneurysm location is unequivocal in diabetic retinopathy (DR) evaluating, the proposed technique was additionally tried on the freely accessible Messidor database, where promising outcomes were seen in a"DR/non-DR"- type classification in view of the nearness or nonappearance of the microaneurysms. [20]

- (Purandare et al, 2016, Hybrid System for Automatic Classification of Diabetic Retinopathy using Fundus images)

The given paper presents a system for automatic classification of subjects as Diabetic Retinopathy and Normal by using fundus images giving impressively fast results during mass screening programs. Clinical features like blood vessel area, exudates area, bifurcation point and non-segmented texture based features were extracted from fundus images by using different techniques which helps in classifying the subjects. SVM is used as the classifier. [21]

- (Jyoti Dnyaneshwar Labhade et al , 2016, Diabetic Retinopathy Detection Using Soft Computing Techniques)

In this work, publically available MESSIDOR database with 1200 fundus images is considered. Texture analysis methods like statistical moments and GLCM are used for extraction of about 40 features. Oversampling is done before classification in order to avoid decrease in accuracy. Classifiers such as Support Vector Machine (SVM), Random Forests, Gradient boost, AdaBoost, Gaussian Naive Bayes are used to detect the DR. Each algorithm has its own advantages and varying accuracy, SVM, however achieved the best accuracy compared to all others. [22]

- (Harini R, 2016, Feature Extraction and Classification of Retinal Images for Automated Detection of Diabetic Retinopathy)

In this proposed method Fuzzy C-means clustering and morphological processing are used for segmentation of blood vessels and morphological operations to detect microaneurysms and exudates from the retinal fundus image. The database includes images from hospital and also 
from publicly available DIARETDB0, DIARETDB1 databases. SVM classifier is used to classify images. The classification is performed based upon values of blood vessel area, microaneurysms area, exudates area, and the textural feature values. The proposed method achieves an excellent sensitivity and satisfactory specificity and accuracy.

\section{- (Sathananthavathi V et al, 2017, Abnormalities} Detection in Retinal Fundus Images)

The proposed method detects the anomalies in retinal fundus image based on dynamic shape features and SVM classifier. Red lesion are detected using two important aids. The first is candidate detection based on pixel classification which separates vasculature and red lesions from the image back ground. After removal of the connected vasculature the remaining objects are considered possible red lesions. Second the detected candidates are used to train the Support Vector Machine (SVM) classifier. An optimal accuracy is achieved by the proposed method for both diartedb1 and stare database by cross training. [23]

- (Sharath Kumar $P$ N al, 2016, Automated Detection System for Diabetic Retinopathy Using Two Field Fundus Photography)

This paper presents a method for automated analysis and classification of the retina as DR or non-DR using two-field mydriatic fundus photography. The optic circle locale is situated by multi-level wavelet decay. Veins are extricated by applying histogram examination on the two middle sifted pictures. Red injuries are identified utilizing three phase power change and white sores from multi-level histogram examination. The last characterization of the retina as DR or non-DR is however in light of injury recognition as it were. The proposed technique has been approved against determination by a board of master ophthalmologists on pictures from 368 patients. The observed sensitivity was higher compared to the specificity. [25]

- (Lachure et al, 2015, Diabetic Retinopathy using Morphological Operations and Machine Learning)

The main objective of this proposed work is to detect retinal microaneurysms and exudates for automatic screening of DR using Support Vector Machine (SVM) and KNN classifier. To build up this proposed framework, an identification of red and brilliant injuries in computerized fundus photos is required. To identify small scale aneurysms, retinal fundus pictures are taken from Messidor, DB-reet dataset. After pre-handling, morphological activities are performed to discover smaller scale aneurysms and after that highlights are removed, for example, GLCM and Structural for grouping. In order to classify the normal and DR images both SVM and KNN were used but SVM gaves better performance as compared to $\mathrm{KNN}$ classifier. [26]

\section{- (Pires et al, 2013, Assessing the Need for Referral in} Automatic Diabetic Retinopathy Detection)

This paper introduces an algorithm to make the decision whether referral is needed or not based on the fusion of results by meta-classification. The contribution of the metaclassifier is the yield of a few sore identifiers, making an intense abnormal state include portrayal for the retinal pictures. Options for the pack of-visual-words (BoVW) are investigated in light of injury identifiers. The last arrangement approach accomplished an AUC of over $90 \%$ utilizing SOFTMAX BoVW (delicate task coding/max pooling), without the need of normalizing the abnormal state highlight vector of scores. [28]

- (Pires et al, 2015, Beyond Lesion-based Diabetic Retinopathy: a Direct Approach for Referral)

In this work lesion detection is bypassed, and classifier is trained directly for DR referral. Additional novelties inculcate the use of mid-level features for the retinal images: BossaNova and Fisher Vector. Those features not only extended the classical Bags of Visual Words but also greatly improved the accuracy of complex classification tasks. An AUC of $96.4 \%$ is achieved, thus reducing the classification error by almost $40 \%$.[29]

- (Rahim et al,2015, Automatic detection of microaneurysms in colour fundus images for diabetic retinopathy screening)

The proposed decision support system consists of an automatic acquisition, screening and classification of diabetic retinopathy colour fundus images, which could be helpful in the detection and management of the diabetic retinopathy. A few element extraction techniques and the round Hough change have been utilized as a part of the proposed microaneurysm location framework, close by the fluffy histogram adjustment strategy. The last technique has been connected in the preprocessing phase of the diabetic retinopathy eye fundus pictures and gave enhanced outcomes to distinguishing the microaneurysms. [30]

- (Roychowdhury et al, 2013, DREAM: Diabetic Retinopathy Analysis using Machine Learning)

A main contribution of this paper is the reduction in the number of features used for lesion classification by feature ranking using Adaboost. A new two-step hierarchical classification approach is proposed where the non-lesions or false positives are rejected in the first step. In the second step, the bright lesions are classified as hard exudates and cotton wool spots, and the red lesions as hemorrhages and micro-aneurysms. This lesion classification problem deals with unbalanced data sets and SVM but is found to incur more classification error than the GMM and kNN classifiers due to the data imbalance. The DR severity grading system is tested on 1200 images from the publicly available MESSIDOR data set. The DREAM system achieves a spectacular $100 \%$ sensitivity and an average specificity and AUC still better as compared to the best reported parametric values for classifying images as with or without DR. The feature reduction further reduces the average computation time for DR severity per image considerably. [31]

- (Rahim et al, 2016, Automatic screening and order of diabetic retinopathy and maculopathy utilizing fluffy picture preparing)

A programmed framework for the consolidated location of diabetic retinopathy and diabetic maculopathy utilizing fluffy picture handling procedures has been proposed here.The system introduces a combination of fuzzy image preprocessing techniques including the retinal structures localization, followed by the feature extraction and, finally, the classification with some machine learning algorithms. The paper also introduces a novel dataset which would be useful to researchers and practitioners working in the field of diabetic retinopathy screening. [19] 
- (Somfai et al, 2014, Automated classifiers for early detection and diagnosis of retinopathy in diabetic eyes)

This study has employed a method that uses a Bayesian ANN with four pairs of input and target features extracted from OCT data to distinguish among MDR, healthy and DM eyes. Intra-retinal layer thickness estimation and aggregate reflectance removed from OCT pictures were utilized as information highlights. The fractal measurement of the GCL + IPL complex and OPL anticipated by the Bayesian outspread premise work arrange decidedly separated amongst MDR and solid eyes. Besides, the thickness and fractal measurement parameters of the RNFL, OS and RPE demonstrate guarantee for symptomatic arrangement amongst MDR and DM eyes. The outcomes exhibited that the proposed framework distinguished and identified retinal highlights with high likelihood for the extent of patients with positive test outcomes who were effectively analyzed. [36]

\begin{tabular}{|c|c|c|c|c|c|c|}
\hline $\begin{array}{l}\text { AUTHOR(ye } \\
\text { ar) }\end{array}$ & $\begin{array}{l}\text { Journal/Co } \\
\text { nference } \\
\text { Title } \\
\end{array}$ & DATASET & PURPOSE & METHODS & $\begin{array}{l}\text { RESULTS } \\
\text { (parameter } \\
\text { s) }\end{array}$ & $\begin{array}{l}\text { LIMITATION } \\
\text { S }\end{array}$ \\
\hline \multicolumn{7}{|c|}{ BASED ON MACHINE LEARNING TECHNIQUES } \\
\hline $\begin{array}{l}\text { B'alint Antal, } \\
\text { Andr'as } \\
\text { Hajdu(2012), } \\
\text { [19] }\end{array}$ & $\begin{array}{l}\text { IEEE } \\
\text { TRANSAC } \\
\text { TIONS ON } \\
\text { BIOMEDIC } \\
\text { AL } \\
\text { ENGINEER } \\
\text { ING }\end{array}$ & Messidor & $\begin{array}{l}\text { Microaneurysm } \\
\text { Detection and } \\
\text { Diabetic } \\
\text { Retinopathy } \\
\text { Grading }\end{array}$ & $\begin{array}{l}\text { Ensemble based } \\
\text { system }\end{array}$ & $\begin{array}{l}0.90 \pm 0.01 \\
\text { AUC }\end{array}$ & $\begin{array}{l}\text { misclassification } \\
\text { at some stage, } \\
\text { where serious } \\
\text { case of DR is } \\
\text { present. }\end{array}$ \\
\hline $\begin{array}{l}\text { Ramon Pires, } \\
\text { Herbert F. } \\
\text { Jelinek, } \\
\text { Jacques } \\
\text { Wainer, } \\
\text { Siome } \\
\text { Goldenstein, } \\
\text { Eduardo } \\
\text { Valle, } \\
\text { Anderson } \\
\text { Rocha(2013), } \\
\text { [28] }\end{array}$ & $\begin{array}{l}\text { IEEE } \\
\text { TRANSAC } \\
\text { TIONS ON } \\
\text { BIOMEDIC } \\
\text { AL } \\
\text { ENGINEER } \\
\text { ING }\end{array}$ & DR1 and DR2 & $\begin{array}{l}\text { Automatic } \\
\text { Diabetic } \\
\text { Retinopathy } \\
\text { Detection }\end{array}$ & $\begin{array}{l}\text { SOFTMAX } \\
\text { BoVW (soft- } \\
\text { assignment } \\
\text { coding / max } \\
\text { pooling) }\end{array}$ & $\begin{array}{l}\text { Area under } \\
\text { the curve of } \\
93.4 \%\end{array}$ & $\begin{array}{l}\text { normalization of } \\
\text { the high-level } \\
\text { feature vector } \\
\text { scores did not } \\
\text { improve on } \\
\text { classification } \\
\text { accuracy }\end{array}$ \\
\hline $\begin{array}{l}\text { Sohini } \\
\text { Roychowdhur } \\
\text { y, Dara D. } \\
\text { Koozekanani, } \\
\text { Keshab K. } \\
\text { Parhi (2013), } \\
\text { [31] }\end{array}$ & $\begin{array}{l}\text { IEEE } \\
\text { Journal of } \\
\text { Biomedical } \\
\text { and Health } \\
\text { Informatics }\end{array}$ & Messidor & $\begin{array}{l}\text { Diabetic } \\
\text { Retinopathy } \\
\text { Analysis using } \\
\text { Machine } \\
\text { Learning }\end{array}$ & $\begin{array}{l}\text { Gaussian } \\
\text { Mixture Model } \\
\text { (GMM), k- } \\
\text { nearest neighbor } \\
\text { (kNN), support } \\
\text { vector machine } \\
\text { (SVM), and } \\
\text { AdaBoost }\end{array}$ & $\begin{array}{l}100 \% \text { sensiti } \\
\text { vity, } 53.16 \% \\
\text { specificity } \\
\text { and } 0.904 \\
\text { AUC }\end{array}$ & $\begin{array}{l}\text { further } \\
\text { improvement in } \\
\text { DR } \\
\text { classification } \\
\text { specificity may } \\
\text { be possible }\end{array}$ \\
\hline $\begin{array}{l}\text { Gábor Márk } \\
\text { Somfai, Erika } \\
\text { Tátrai, Lenke } \\
\text { Laurik, } \\
\text { Boglárka } \\
\text { Varga, } \\
\text { Veronika } \\
\text { Ölvedy, Hong } \\
\text { Jiang, Jianhua } \\
\text { Wang, } \\
\text { William E } \\
\text { Smiddy, } \\
\text { Anikó } \\
\text { Somogyi and } \\
\text { Delia Cabrera } \\
\text { DeBuc(2014), } \\
\text { [36] }\end{array}$ & $\begin{array}{l}\text { BMC } \\
\text { Bioinfomati } \\
\text { cs }\end{array}$ & $\begin{array}{l}\text { OCT images } \\
\text { of private } \\
\text { dataset(190) }\end{array}$ & $\begin{array}{l}\text { early detection } \\
\text { and } \\
\text { diagnosis of } \\
\text { retinopathy in } \\
\text { diabetic eyes }\end{array}$ & Bayesian ANN & $\begin{array}{l}\text { sensitivity, } \\
\text { specificity } \\
\text { and PPV are } \\
\text { greater or } \\
\text { close to } 0.70\end{array}$ & Small dataset \\
\hline $\begin{array}{l}\text { Karthikeyan } \\
\text { Ganesan, }\end{array}$ & $\begin{array}{l}\text { Medical \& } \\
\text { biological }\end{array}$ & $\begin{array}{l}\text { Private } \\
\text { database, }\end{array}$ & $\begin{array}{l}\text { Computer?aide } \\
\text { d diabetic }\end{array}$ & $\begin{array}{l}\text { trace } \\
\text { transforms, }\end{array}$ & $\begin{array}{l}\text { accuracy of } \\
99.41 \text { and }\end{array}$ & Small database \\
\hline
\end{tabular}




\begin{tabular}{|c|c|c|c|c|c|c|}
\hline $\begin{array}{l}\text { Roshan Joy } \\
\text { Martis, } \\
\text { Rajendra } \\
\text { Acharya, } \\
\text { Chua Kuang } \\
\text { Chu, Lim } \\
\text { Choo Min, E. } \\
\text { Y. K. N, } \\
\text { Augustinus } \\
\text { Laude(2014), } \\
\text { [24] }\end{array}$ & $\begin{array}{l}\text { engineering } \\
\& \\
\text { computing, } \\
\text { Springer }\end{array}$ & $\begin{array}{l}\text { MESSIDOR } \\
(170)\end{array}$ & $\begin{array}{l}\text { retinopathy } \\
\text { detection using } \\
\text { trace transforms } \\
\text { on digital } \\
\text { fundus images }\end{array}$ & $\begin{array}{l}\text { support vector } \\
\text { machine (SVM) } \\
\text { with quadratic, } \\
\text { polynomial, } \\
\text { radial basis } \\
\text { function kernels } \\
\text { and } \\
\text { probabilistic } \\
\text { neural network, } \\
\text { genetic } \\
\text { algorithm } \\
\end{array}$ & $\begin{array}{l}99.12 \% \\
\text { with Pnn-ga } \\
\text { and SVM } \\
\text { quadratic } \\
\text { kernels }\end{array}$ & \\
\hline $\begin{array}{l}\text { G. } \\
\text { Mahendran, } \\
\text { R. } \\
\text { Dhanasekaran } \\
(2015),[34]\end{array}$ & $\begin{array}{l}\text { Computers } \\
\text { and } \\
\text { Electrical } \\
\text { Engineering, } \\
\text { Elsevier }\end{array}$ & Messidor & $\begin{array}{l}\text { Investigation of } \\
\text { the severity } \\
\text { level of diabetic } \\
\text { retinopathy }\end{array}$ & $\begin{array}{l}\text { support vector } \\
\text { machine (SVM) } \\
\text { and } \\
\text { probabilistic } \\
\text { neural network } \\
(\mathrm{PNN})\end{array}$ & $\begin{array}{l}\text { accuracy for } \\
\text { the SVM } \\
\text { and } \\
\text { PNN } \\
\text { classifiers } \\
\text { are } \\
\text { determined } \\
\text { to be } \\
97.89 \% \text { and } \\
94.76 \% \text {, } \\
\text { respectively }\end{array}$ & $\begin{array}{l}\text { System does not } \\
\text { identify mild } \\
\text { DR cases }\end{array}$ \\
\hline $\begin{array}{l}\text { Sarni Suhaila } \\
\text { Rahim, } \\
\text { Chrisina } \\
\text { Jayne, Vasile } \\
\text { Palade, James } \\
\text { Shuttleworth( } \\
\text { 2015), [30] }\end{array}$ & $\begin{array}{l}\text { The Natural } \\
\text { Computing } \\
\text { Applications } \\
\text { Forum } 2015\end{array}$ & $\begin{array}{l}\text { DIARETDB0 } \\
\text { for system } 1 \\
\text { and } \\
\text { DIARETDB1 } \\
\text { for system } 2 \\
\text { And ROC for } \\
\text { sys } 3 \text { and } 4\end{array}$ & $\begin{array}{l}\text { Automatic } \\
\text { detection of } \\
\text { microaneurysms } \\
\text { in colour fundus } \\
\text { images for } \\
\text { diabetic } \\
\text { retinopathy } \\
\text { screening }\end{array}$ & $\begin{array}{l}\text { k-nearest } \\
\text { neighbour } \\
\text { classifier and } \\
\text { SVM, } \\
\text { Greyscale } \\
\text { conversion and } \\
\text { shade correction } \\
\text { preprocessing } \\
\text { techniques for } \\
\text { sys } 1 \text { and } 2 \\
\text { circular Hough } \\
\text { transform for } \\
\text { sys } 3 \text {, fuzzy } \\
\text { preprocessing } \\
\text { technique for } \\
\text { sys } 4\end{array}$ & $\begin{array}{l}\text { accuracy of } \\
\text { the binary } \\
\text { decision tree } \\
\text { and the } 1 \text { - } \\
\text { nearest } \\
\text { neighbour, } \\
\text { is } 0.9091 \text {, } \\
\text { while that } \\
\text { for the } \\
\text { radial basis } \\
\text { function } \\
\text { kernel-based } \\
\text { support } \\
\text { vector } \\
\text { classifier } \\
\text { and the } \\
\text { second- } \\
\text { order } \\
\text { polynomial } \\
\text { kernel-based } \\
\text { support } \\
\text { vector } \\
\text { classifier is } \\
0.7273 \text {. }\end{array}$ & $\begin{array}{l}\text { Specificity, } \\
\text { sensitivity and } \\
\text { accuracy can be } \\
\text { enhanced }\end{array}$ \\
\hline $\begin{array}{l}\text { Jaykurnar } \\
\text { Lachure, A. V } \\
\text {.Deorankar, } \\
\text { Sagar } \\
\text { Lachure, } \\
\text { Swati Gupta, } \\
\text { Romit } \\
\text { Jadhav(2015), } \\
{[26]}\end{array}$ & $\begin{array}{l}\text { IEEE } \\
\text { International } \\
\text { Advance } \\
\text { Computing } \\
\text { Conference } \\
\text { (IACC) }\end{array}$ & $\begin{array}{l}\text { MESSIDOR, } \\
\text { Diabeticret } \\
\text { DB } 1\end{array}$ & $\begin{array}{l}\text { Diabetic } \\
\text { Retinopathy } \\
\text { using } \\
\text { Morphological } \\
\text { Operations and } \\
\text { Machine } \\
\text { Learning }\end{array}$ & $\begin{array}{l}\text { Support Vector } \\
\text { Machine (SVM) } \\
\text { and KNN } \\
\text { classifier }\end{array}$ & $\begin{array}{l}\text { specificity is } \\
100 \% \text { and } \\
\text { sensitivity is } \\
\text { more than } \\
90 \% \text { for } \\
\text { SVM }\end{array}$ & $\begin{array}{l}\text { KNN fails in the } \\
\text { given scenario }\end{array}$ \\
\hline $\begin{array}{l}\text { Ramon Pires, } \\
\text { Sandra Avila, } \\
\text { Herbert F. } \\
\text { Jelinek, } \\
\text { Jacques } \\
\text { Wainer, } \\
\text { Eduardo } \\
\text { Valle, }\end{array}$ & $\begin{array}{l}\text { IEEE } \\
\text { Journal of } \\
\text { Biomedical } \\
\text { and Health } \\
\text { Informatics }\end{array}$ & $\begin{array}{l}\text { DR2 and } \\
\text { MESSIDOR }\end{array}$ & $\begin{array}{l}\text { Direct } \\
\text { Approach for } \\
\text { Referral } \\
\text { bypassing lesion } \\
\text { detection }\end{array}$ & $\begin{array}{l}\text { advanced mid- } \\
\text { level features } \\
\text { (BossaNova and } \\
\text { Fisher Vector), } \\
\text { Bags of Visual } \\
\text { Words (BoVW) } \\
\text { model and } \\
\text { maximum- }\end{array}$ & $\begin{array}{l}\text { area under } \\
\text { the curve } \\
\text { (AUC) of } \\
96.4 \%\end{array}$ & $\begin{array}{l}\text { automated } \\
\text { decision with } \\
\text { respect to DR } \\
\text { progression is } \\
\text { missing }\end{array}$ \\
\hline
\end{tabular}




\begin{tabular}{|c|c|c|c|c|c|c|}
\hline $\begin{array}{l}\text { Anderson } \\
\text { Rocha(2015), } \\
\text { [29] }\end{array}$ & & & & $\begin{array}{l}\text { margin (SVM) } \\
\text { classifiers }\end{array}$ & & \\
\hline $\begin{array}{l}\text { Sarni Suhaila } \\
\text { Rahim, Vasile } \\
\text { Palade, James } \\
\text { Shuttleworth . } \\
\text { Chrisina } \\
\text { Jayne(2016), } \\
\text { [19] }\end{array}$ & $\begin{array}{l}\text { Brain } \\
\text { Informatics } \\
(2016)\end{array}$ & $\begin{array}{l}\text { Private } \\
\text { dataset } \\
\text { created and } \\
\text { available for } \\
\text { public use }\end{array}$ & $\begin{array}{l}\text { Automatic } \\
\text { screening and } \\
\text { classification of } \\
\text { diabetic } \\
\text { retinopathy and } \\
\text { maculopathy }\end{array}$ & $\begin{array}{l}\text { K-nearest } \\
\text { neighbour, } \\
\text { support vector } \\
\text { machines and } \\
\text { Naïve bayes } \\
\text { classifier and } \\
\text { fuzzy } \\
\text { techniques fir } \\
\text { preprocessing }\end{array}$ & $\begin{array}{l}\text { Accuracy } \\
0.9300(\mathrm{KN} \\
\mathrm{N}) \\
0.7000(\mathrm{SV} \\
\mathrm{M}) \\
0.9300(\mathrm{RBF} \\
\text { kernel } \\
\text { SVM) } \\
0.7500(\text { Naiv } \\
\text { eBayes) }\end{array}$ & $\begin{array}{l}\text { Sensitivity was } \\
\text { less than } \\
\text { specificity for } \\
\text { maculopathy } \\
\text { detection }\end{array}$ \\
\hline $\begin{array}{l}\text { Sharath } \\
\text { Kumar P N, } \\
\text { Deepak R U, } \\
\text { Anuja } \\
\text { Satharb, } \\
\text { Sahasranama } \\
\text { m V, Rajesh } \\
\text { Kumar } \\
\text { R(2016), [25] }\end{array}$ & $\begin{array}{l}\text { International } \\
\text { Conference } \\
\text { On } \\
\text { Advances In } \\
\text { Computing } \\
\text { \& } \\
\text { Communicat } \\
\text { ions, ICACC } \\
2016\end{array}$ & $\begin{array}{l}\text { Private } \\
\text { database }\end{array}$ & $\begin{array}{l}\text { Automated } \\
\text { Detection } \\
\text { System for } \\
\text { Diabetic } \\
\text { Retinopathy } \\
\text { Using Two } \\
\text { Field Fundus } \\
\text { Photography }\end{array}$ & $\begin{array}{l}\text { Waterfall model } \\
\text { based } \\
\text { classification }\end{array}$ & $\begin{array}{l}\text { sensitivity } \\
\text { and } \\
\text { specificity } \\
\text { are } 80 \% \text { and } \\
50 \%\end{array}$ & $\begin{array}{l}\text { detection rate of } \\
\text { mild NPDR } \\
\text { cases is not } \\
\text { satisfiable }\end{array}$ \\
\hline $\begin{array}{l}\text { Harini R } \\
\text { Sheela } \\
\text { N(2016), [33] }\end{array}$ & $\begin{array}{l}2016 \text { Second } \\
\text { International } \\
\text { Conference } \\
\text { on Cognitive } \\
\text { Computing } \\
\text { and } \\
\text { Information } \\
\text { Processing } \\
\text { (CCIP), } \\
\text { IEEE } \\
\end{array}$ & $\begin{array}{l}\text { Private } \\
\text { database, } \\
\text { DIARETDB0 } \\
\text { DIARETDB1 } \\
(75)\end{array}$ & $\begin{array}{l}\text { Automated } \\
\text { Detection of } \\
\text { Diabetic } \\
\text { Retinopathy } \\
\text { through Feature } \\
\text { Extraction and } \\
\text { Classification of } \\
\text { Retinal Images }\end{array}$ & $\begin{array}{l}\text { Fuzzy C-Means } \\
\text { (FCM) } \\
\text { clustering } \\
\text { morphological } \\
\text { image } \\
\text { processing and } \\
\text { Support Vector } \\
\text { Machine (SVM) } \\
\text { classifier }\end{array}$ & $\begin{array}{l}\text { Accuracy of } \\
96.67 \%, \\
\text { Sensitivity } \\
\text { of } 100 \% \text {, } \\
\text { and } \\
\text { Specificity } \\
\text { of } 95.83 \% \text {. }\end{array}$ & Small database \\
\hline $\begin{array}{l}\text { Jyoti } \\
\text { Dnyaneshwar } \\
\text { Labhade, } \\
\text { L. K. } \\
\text { Chouthmol, } \\
\text { Suraj } \\
\text { Deshmukh(20 } \\
\text { 16), [22] }\end{array}$ & $\begin{array}{l}2016 \\
\text { International } \\
\text { Conference } \\
\text { on } \\
\text { Automatic } \\
\text { Control and } \\
\text { Dynamic } \\
\text { Optimizatio } \\
\text { n } \\
\text { Techniques } \\
\text { (ICACDOT) } \\
\text {, IEEE }\end{array}$ & $\begin{array}{l}\text { Messidor } \\
(1200)\end{array}$ & $\begin{array}{l}\text { Diabetic } \\
\text { Retinopathy } \\
\text { Detection }\end{array}$ & $\begin{array}{l}\text { Support Vector } \\
\text { Machine } \\
\text { (SVM), } \\
\text { Random } \\
\text { Forests, } \\
\text { Gradient boost, } \\
\text { AdaBoost, } \\
\text { Gaussian Naive } \\
\text { Bayes, texture } \\
\text { analysis }\end{array}$ & $\begin{array}{l}\text { SVM } \\
\text { accuracy } \\
88.71 \%, \\
\text { Random } \\
\text { forests } \\
\text { technique } \\
\text { accuracy } \\
83.34 \% \text {, } \\
\text { Gradient } \\
\text { boost } \\
\text { algorithm } \\
\text { accuracy } \\
83.34 \%, \\
\text { AdaBoost } \\
\text { accuracy } \\
54.3 \% \text { and } \\
\text { Gaussian } \\
\text { Naïve Bayes } \\
\text { methods } \\
\text { accuracy } \\
37.09 \% \text {. }\end{array}$ & $\begin{array}{l}\text { Gaussian NB } \\
\text { and AdaBoost } \\
\text { classifier } \\
\text { demonstrated } \\
\text { poor accuracy in } \\
\text { the given } \\
\text { scenario }\end{array}$ \\
\hline $\begin{array}{l}\text { Manasi } \\
\text { Purandare, } \\
\text { Kevin } \\
\text { Noronha } \\
(2016),[21]\end{array}$ & $\begin{array}{l}2016 \text { Online } \\
\text { International } \\
\text { Conference } \\
\text { on Green } \\
\text { Engineering } \\
\text { and } \\
\text { Technologie } \\
\text { s (IC-GET), } \\
\text { IEEE }\end{array}$ & $\begin{array}{l}\text { Private } \\
\text { database }\end{array}$ & $\begin{array}{l}\text { Classification of } \\
\text { Diabetes } \\
\text { Retinopathy } \\
\text { using Fundus } \\
\text { images }\end{array}$ & $\begin{array}{l}\text { texture based } \\
\text { feature } \\
\text { extraction and } \\
\text { SVM classifier }\end{array}$ & $\begin{array}{l}\text { accuracy of } \\
92.55 \%, \\
\text { specificity } \\
\text { of } 96 \%, \\
\text { sensitivity } \\
\text { of } 78 \%, \mathrm{PPV} \\
\text { of } 95.12 \%\end{array}$ & $\begin{array}{l}\text { Performance } \\
\text { degradation } \\
\text { when working } \\
\text { with small } \\
\text { database }\end{array}$ \\
\hline Manuel E. & Computers & NASMC, & automated & Local regression & 0.9380 per & The system is \\
\hline
\end{tabular}




\begin{tabular}{|c|c|c|c|c|c|c|}
\hline $\begin{array}{l}\text { Gegundez- } \\
\text { Arias, Diego } \\
\text { Marin, } \\
\text { Beatriz Ponte, } \\
\text { Fatima } \\
\text { Alvarez, } \\
\text { Javier Garrido } \\
\text { Carlos } \\
\text { Ortega, } \\
\text { Manuel J. } \\
\text { Vasallo, Jose } \\
\text { M. } \\
\text { Bravo(2017), } \\
\text { [35] }\end{array}$ & $\begin{array}{l}\text { in Biology } \\
\text { and } \\
\text { Medicine, } \\
\text { Elsevier }\end{array}$ & $\begin{array}{l}\text { JRJHH } \\
\text { and VMUHH } \\
\text { medical } \\
\text { centres }\end{array}$ & $\begin{array}{l}\text { diabetic } \\
\text { retinopathy pre- } \\
\text { screening based } \\
\text { on retinal } \\
\text { image computer } \\
\text { analysis }\end{array}$ & $\begin{array}{l}\text { classifier and } \\
\text { digital image } \\
\text { processing for } \\
\text { detection of } \\
\text { lesions }\end{array}$ & $\begin{array}{l}\text { patient } \\
\text { sensitivity } \\
\text { and } 0.5098 \\
\text { specificity }\end{array}$ & $\begin{array}{l}\text { environment } \\
\text { specific not } \\
\text { tested against } \\
\text { any public } \\
\text { datanases }\end{array}$ \\
\hline $\begin{array}{l}\text { Ravindranath } \\
\text { Tagore } \\
\text { Mamilla, } \\
\text { Venkata } \\
\text { Krishna Rao } \\
\text { Ede, } \\
\text { Prabhakar } \\
\text { Rao } \\
\text { Bhima(2017), } \\
\text { [27] }\end{array}$ & $\begin{array}{l}\text { Springer, } \\
\text { Journal of } \\
\text { Medical and } \\
\text { Biological } \\
\text { Engineering }\end{array}$ & $\begin{array}{l}\text { DIARETDB0 } \\
\text { and } \\
\text { DIARETDB1 } \\
(400)\end{array}$ & $\begin{array}{l}\text { Automatic red } \\
\text { lesion detection }\end{array}$ & $\begin{array}{l}\text { SVM classifier } \\
\text { and KNN } \\
\text { classifier }\end{array}$ & $\begin{array}{l}\text { sensitivity } \\
\text { and } \\
\text { specificity } \\
\text { hybrid } \\
\text { detection } \\
\text { method with } \\
\text { SVM is } 100 \\
\text { and } 87.50 \% \\
\text { against } \\
96.72 \text { and } \\
75 \% \text { for } \\
\text { with KNN }\end{array}$ & Small dataset \\
\hline $\begin{array}{l}\text { Wei Zhou, } \\
\text { Chengdong } \\
\text { Wu, Dali } \\
\text { Chen, Yugen } \\
\text { Y, and } \\
\text { Wenyou } \\
\text { Du(2017), } \\
\text { [32] }\end{array}$ & IEEE Access & $\begin{array}{l}\text { Retinopathy } \\
\text { Online } \\
\text { Challenge } \\
\text { (ROC) } \\
\text { database }\end{array}$ & $\begin{array}{l}\text { Automatic } \\
\text { Microaneurysm } \\
\text { Detection }\end{array}$ & $\begin{array}{l}\text { Unsupervised } \\
\text { classification } \\
\text { method based } \\
\text { on sparse } \\
\text { posterior } \\
\text { cerebral artery } \\
\text { (PCA) }\end{array}$ & AUC 0.275 & $\begin{array}{l}\text { proposed } \\
\text { framework does } \\
\text { not detect other } \\
\text { lesions such as } \\
\text { hard exudates } \\
\text { and } \\
\text { hemorrhages, } \\
\text { texture feature } \\
\text { not included }\end{array}$ \\
\hline $\begin{array}{l}\text { V.Sathananth } \\
\text { avathi, } \\
\text { G.Indumathi, } \\
\text { R.Rajalakshm } \\
\text { i(2017), [23] }\end{array}$ & $\begin{array}{l}\text { International } \\
\text { Conference } \\
\text { on Inventive } \\
\text { Communicat } \\
\text { ion and } \\
\text { Computation } \\
\text { al } \\
\text { Technologie } \\
\text { s } \\
\text { (ICICCT } \\
\text { 2017), IEEE }\end{array}$ & $\begin{array}{l}\text { Diaretdb1 and } \\
\text { STARE } \\
\text { databases }\end{array}$ & $\begin{array}{l}\text { development of } \\
\text { an automatic } \\
\text { telemedicine } \\
\text { system for } \\
\text { screening and } \\
\text { grading of } \\
\text { Diabetic } \\
\text { Retinopathy } \\
\text { depends (DR) } \\
\text { on reliable } \\
\text { detection of } \\
\text { abnormalities in } \\
\text { retinal fundus } \\
\text { images }\end{array}$ & $\begin{array}{l}\text { dynamic shape } \\
\text { feature } \\
\text { extraction and } \\
\text { SVM classifier }\end{array}$ & $\begin{array}{l}\text { accuracy of } \\
90 \% \text { for } \\
\text { diartedb1 } \\
\text { database and } \\
80 \% \text { for } \\
\text { stare } \\
\text { database by } \\
\text { cross } \\
\text { training. }\end{array}$ & $\begin{array}{l}\text { type of } \\
\text { abnormalities } \\
\text { present in the } \\
\text { fundus images is } \\
\text { not detected by } \\
\text { the proposed } \\
\text { method }\end{array}$ \\
\hline
\end{tabular}


Theoretical Difference Analysis

\begin{tabular}{|l|l|}
\hline DEEP LEARNING BASED TECHNIQUES & MACHINE LEARNING BASED TECHNIQUES \\
\hline \multicolumn{2}{|c|}{ 1. Neural networks } \\
\hline $\begin{array}{l}\text { When the problem does exhibit nonlinear properties, } \\
\text { deep networks seem computationally more attractive } \\
\text { than shallow networks. }\end{array}$ & $\begin{array}{l}\text { For the same problem, in order to get to the same level } \\
\text { of performance as of a deep network, a shallow network } \\
\text { requires many more connections thus being more } \\
\text { computationally expensive. }\end{array}$ \\
\hline 2. Kernel methods & $\begin{array}{l}\text { Kernel methods in machine learning can be expensive in } \\
\text { practice. This is because they keep a list of support } \\
\text { vectors which can be large thus effecting computation of } \\
\text { the decision function. }\end{array}$ \\
\hline $\begin{array}{l}\text { There is no problem with deep networks thus making } \\
\text { them more suitable for big problem sets. }\end{array}$ & $\begin{array}{l}\text { Machine learning methods are comparatively less } \\
\text { flexible. }\end{array}$ \\
\hline 3. Flexibility & $\begin{array}{l}\text { For tasks that require great computational and human } \\
\text { resource capacity, classic machine learning strategies are } \\
\text { not suitable. }\end{array}$ \\
\hline $\begin{array}{l}\text { Deep networks are more flexible i.e., they can be } \\
\text { modified in many ways to suit the tasks. }\end{array}$ \\
\hline $\begin{array}{l}\text { 4. Resource capacity } \\
\text { Deep convolutional neural networks can handle } \\
\text { enormous amount of information, the size of which is in } \\
\text { millions. }\end{array}$ \\
\hline $\begin{array}{l}\text { 5. Linear vs. non linear data } \\
\text { Deep learning can handle both type of data intensive } \\
\text { problems equally good i.e., linear and non linear. }\end{array}$ & $\begin{array}{l}\text { For the non linear case, machine learning lags in terms } \\
\text { of performance. }\end{array}$ \\
\hline
\end{tabular}

\begin{tabular}{|l|l|l|}
\hline \multicolumn{2}{|c|}{ Parametric Disparity Analysis } \\
\hline PARAMETERS & MACHINE LEARNING & DEEP LEARNING \\
\hline Hata Requirements & Small & Large \\
\hline Learning & CPUs & GPUs \\
\hline Expert Analysis & Supervised & Unsupervised \\
\hline Modularity & Required & Not Required \\
\hline Problem Solving & Present & Absent \\
\hline Execution time & Modular & End to End \\
\hline Interoperability & Less & More \\
\hline Transparency & Supported & Not Supported \\
\hline Merits & More & Less \\
\hline Demerits & $\begin{array}{l}\text { Used in case of small data and } \\
\text { perform well, modular approach } \\
\text { reduces complexity of overall } \\
\text { operation }\end{array}$ & $\begin{array}{l}\text { Large datasets are supported with } \\
\text { complex problem solving. } \\
\text { Unsupervised learning mechanism } \\
\text { reduces requirements of expert and } \\
\text { hence useful for even naive user }\end{array}$ \\
\hline & $\begin{array}{l}\text { Complex environment with modern } \\
\text { day datasets cannot be handled } \\
\text { especially in the field of image } \\
\text { mining }\end{array}$ & $\begin{array}{l}\text { Transparency could be an issue in deep } \\
\text { learning }\end{array}$ \\
\hline
\end{tabular}

\section{CONCLUSION}

The present review has addressed different deep learning, machine learning techniques that are deployed for DR diagnosis. The techniques and algorithms that were extensively used are convolutional neural networks, artificial neural networks, support vector machines, fuzzy logic, bag of words algorithms and so on. A comparison pertaining to the supremacy of deep learning techniques over existing machine learning techniques is also stated in 
terms of data requirements, learning, etc which is the need of the hour as the medical database is ever increasing phenomena demanding faster results. Though these studies are vast, this spectrum of research requires more rigorous investigation in terms of classification with minimal errors.

\section{REFERENCES}

[1] Tan, J. H., Fujita, H., Sivaprasad, S., Bhandary, S. V., Rao, A. K., Chua, K. C., \& Acharya, U. R. (2017). Automated segmentation of exudates, haemorrhages, microaneurysms using single convolutional neural network. Information Sciences, 420, 66-76. DOI: 10.1016/j.ins.2017.08.050

[2] van Grinsven, M. J., van Ginneken, B., Hoyng, C. B., Theelen, T., \& Sánchez, C. I. (2016). Fast convolutional neural network training using selective data sampling: Application to hemorrhage detection in color fundus images. IEEE transactions on medical imaging, 35(5), 1273-1284. DOI 10.1109/TMI.2016.2526689

[3] Abbas, Q., Fondon, I., Sarmiento, A., Jiménez, S., \& Alemany, P. (2017). Automatic recognition of severity level for diagnosis of diabetic retinopathy using deep visual features. Medical \& Biological Engineering \& Computing, 1-16. DOI 10.1007/s11517-017-1638-6

[4] Doshi, D., Shenoy, A., Sidhpura, D., \& Gharpure, P. (2016, December). Diabetic retinopathy detection using deep convolutional neural networks. In Computing, Analytics and Security Trends (CAST), International Conference on (pp. 261-266). IEEE. DOI: 10.1109/CAST.2016.7914977

[5] Quellec, G., Charrière, K., Boudi, Y., Cochener, B., \& Lamard, M. (2017). Deep image mining for diabetic retinopathy screening. Medical Image Analysis, 39, 178193.DOI: 10.1016/j.media.2017.04.012

[6] Pratt, H., Coenen, F., Broadbent, D. M., Harding, S. P., \& Zheng, Y. (2016). Convolutional neural networks for diabetic retinopathy. Procedia Computer Science, 90, 200205. DOI: 10.1016/j.procs.2016.07.014

[7] Gargeya, R., \& Leng, T. (2017). Automated Identification of Diabetic Retinopathy Using Deep Learning. Ophthalmology. DOI: 10.1016/j.ophtha.2017.02.008 ISSN

[8] Colas, E., Besse, A., Orgogozo, A., Schmauch, B., Meric, N., \& Besse, E. (2016). Deep learning approach for diabetic retinopathy screening. Acta Ophthalmologica, 94(S256). DOI: $10.1111 /$ j. 1755-3768.2016.0635

[9] Roy, P., Tennakoon, R., Cao, K., Sedai, S., Mahapatra, D., Maetschke, S., \& Garnavi, R. (2017, April). A novel hybrid approach for severity assessment of Diabetic Retinopathy in colour fundus images. In, 2017 IEEE 14th International Symposium on Biomedical Imaging (ISBI 2017) (pp. 10781082). IEEE. DOI: 10.1109/ISBI.2017.7950703

[10] Paul, S., \& Singh, L. (2016, December). Heterogeneous modular deep neural network for diabetic retinopathy detection. In Humanitarian Technology Conference (R10HTC), 2016 IEEE Region 10 (pp. 1-6). IEEE. DOI: 10.1109/R10-HTC.2016.7906821

[11] Takahashi, H., Tampo, H., Arai, Y., Inoue, Y., \& Kawashima, H. (2017). Applying artificial intelligence to disease staging: Deep learning for improved staging of diabetic retinopathy. PloS one, 12(6), e0179790. DOI: 10.1371/journal.pone. 0179790

[12] ElTanboly, A., Ismail, M., Shalaby, A., Switala, A., El Baz, A., Schaal, S., ... \& El Azab, M. (2017). A computer aided diagnostic system for detecting diabetic retinopathy in optical coherence tomography images. Medical physics, 44(3), 914-923. DOI: 10.1002/mp.12071

[13] Gulshan, V., Peng, L., Coram, M., Stumpe, M. C., Wu, D., Narayanaswamy, A., ... \& Kim, R. (2016). Development and validation of a deep learning algorithm for detection of diabetic retinopathy in retinal fundus photographs. Jama, 316(22), 2402-2410. DOI: 10.1001/jama.2016.17216

[14] Prentašić, P., \& Lončarić, S. (2016). Detection of exudates in fundus photographs using deep neural networks and anatomical landmark detection fusion. Computer methods and programs in biomedicine, 137, 281-292. DOI: 10.1016/j.cmpb.2016.09.018

[15] Prentašić, P., \& Lončarić, S. (2015, September). Detection of exudates in fundus photographs using convolutional neural networks. In Image and Signal Processing and Analysis (ISPA), 2015 9th International Symposium on (pp. 188-192). IEEE. DOI: 10.1109/ISPA.2015.7306056

[16] Shan, J., \& Li, L. (2016, June). A deep learning method for microaneurysm detection in fundus images. In Connected Health: Applications, Systems and Engineering Technologies (CHASE), 2016 IEEE First International Conference on (pp. 357-358). IEEE. DOI 10.1109/CHASE.2016.12

[17] Costa, P., \& Campilho, A. (2017). Convolutional bag of words for diabetic retinopathy detection from eye fundus images. IPSJ Transactions on Computer Vision and Applications, 9(1), 10. DOI: 10.1186/s41074-017-0023-6

[18] Vo, H. H., \& Verma, A. (2016, December). New Deep Neural Nets for Fine-Grained Diabetic Retinopathy Recognition on Hybrid Color Space. In Multimedia (ISM), 2016 IEEE International Symposium on (pp. 209-215). IEEE. DOI 10.1109/ISM.2016.99

[19] Rahim, S. S., Palade, V., Shuttleworth, J., \& Jayne, C. (2016). Automatic screening and classification of diabetic retinopathy and maculopathy using fuzzy image processing. Brain informatics, 3(4), 249-267. DOI 10.1007/s00521-0151929-5

[20] Antal, B., \& Hajdu, A. (2012). An ensemble-based system for microaneurysm detection and diabetic retinopathy grading. IEEE transactions on biomedical engineering, 59(6), 1720-1726. DOI: 10.1109/TBME.2012.2193126

[21] Purandare, M., \& Noronha, K. (2016, November). Hybrid system for automatic classification of Diabetic Retinopathy using fundus images. In Green Engineering and Technologies (IC-GET), 2016 Online International Conference on (pp. 1-5). IEEE. DOI: 10.1109/GET.2016.7916623

[22] Labhade, J. D., Chouthmol, L. K., \& Deshmukh, S. (2016, September). Diabetic retinopathy detection using soft computing techniques. In Automatic Control and Dynamic Optimization Techniques (ICACDOT), International Conference on (pp. 175-178). IEEE. DOI: 10.1109/ICACDOT.2016.7877573

[23] Sathananthavathi, V., Indumathi, G., \& Rajalakshmi, R. (2017, March). Abnormalities detection in retinal fundus images. In Inventive Communication and Computational Technologies (ICICCT), 2017 International Conference on (pp. 89-93). IEEE. DOI: 10.1109/ICICCT.2017.7975165

[24] Ganesan, K., Martis, R. J., Acharya, U. R., Chua, C. K., Min, L. C., Ng, E. Y. K., \& Laude, A. (2014). Computer-aided diabetic retinopathy detection using trace transforms on digital fundus images. Medical \& biological engineering \& computing, 52(8), 663-672. DOI 10.1007/s11517-014-11675

[25] Kumar, P. S., Deepak, R. U., Sathar, A., Sahasranamam, V., \& Kumar, R. R. (2016). Automated Detection System for Diabetic Retinopathy Using Two Field Fundus Photography. Procedia Computer Science, 93, 486-494. DOI : 10.1016/j.procs.2016.07.237

[26] Lachure, J., Deorankar, A. V., Lachure, S., Gupta, S., \& Jadhav, R. (2015, June). Diabetic Retinopathy using morphological operations and machine learning. In Advance Computing Conference (IACC), 2015 IEEE International (pp. 617-622). IEEE. DOI: 10.1109/IADCC.2015.7154781 
[27] Mamilla, R. T., Ede, V. K. R., \& Bhima, P. R. (2017). Extraction of Microaneurysms and Hemorrhages from Digital Retinal Images. Journal of Medical and Biological Engineering, 37(3), 395-408. DOI 10.1007/s40846-0170237-1

[28] Pires, R., Jelinek, H. F., Wainer, J., Goldenstein, S., Valle, E., \& Rocha, A. (2013). Assessing the need for referral in automatic diabetic retinopathy detection. IEEE Transactions on Biomedical Engineering, 60(12), 3391-3398. DOI: 10.1109/TBME.2013.2278845

[29] Pires, R., Avila, S., Jelinek, H. F., Wainer, J., Valle, E., \& Rocha, A. (2017). Beyond lesion-based diabetic retinopathy: a direct approach for referral. IEEE journal of biomedical and health informatics, 21(1), 193-200. DOI 10.1109/JBHI.2015.2498104

[30] Rahim, S. S., Jayne, C., Palade, V., \& Shuttleworth, J. (2016). Automatic detection of microaneurysms in colour fundus images for diabetic retinopathy screening. Neural Computing and Applications, 27(5), 1149-1164, DOI 10.1007/s40708016-0045-3.

[31] Roychowdhury, S., Koozekanani, D. D., \& Parhi, K. K. (2014). DREAM: diabetic retinopathy analysis using machine learning. IEEE journal of biomedical and health $\begin{array}{lll}\text { informatics, } & 18(5), & 1717-1728 .\end{array}$ 10.1109/JBHI.2013.2294635
[32] Zhou, W., Wu, C., Chen, D., Yi, Y., \& Du, W. (2017). Automatic Microaneurysm Detection Using the Sparse Principal Component Analysis-Based Unsupervised Classification Method. IEEE Access, 5, 2563-2572. DOI 10.1109/ACCESS.2017.267191

[33] Harini, R., \& Sheela, N. (2016, August). Feature extraction and classification of retinal images for automated detection of Diabetic Retinopathy. In Cognitive Computing and Information Processing (CCIP), 2016 Second International Conference on (pp. 1-4). IEEE. DOI: 10.1109/CCIP.2016.7802862

[34] Mahendran, G., \& Dhanasekaran, R. (2015). Investigation of the severity level of diabetic retinopathy using supervised classifier algorithms. Computers \& Electrical Engineering, 45, 312-323. DOI: 10.1016/j.compeleceng.2015.01.013

[35] Gegundez-Arias, M. E., Marin, D., Ponte, B., Alvarez, F., Garrido, J., Ortega, C., \& Bravo, J. M. (2017). A tool for automated diabetic retinopathy pre-screening based on retinal image computer analysis. Computers in Biology and Medicine. DOI:10.1016/j.compbiomed.2017.07.007

[36] Somfai, G. M., Tátrai, E., Laurik, L., Varga, B., Ölvedy, V., Jiang, H., \& DeBuc, D. C. (2014). Automated classifiers for early detection and diagnosis of retinopathy in diabetic eyes. BMC bioinformatics, 15(1), 106. DOI: 10.1186/1471-210515-106 